Int. J. Dev. Biol. 48: 000-000 (2004)

doi: $10.1387 / \mathrm{ijdb} .041865 \mathrm{dg}$

\title{
Anterior segment development relevant to glaucoma
}

\author{
DOUGLAS B. GOULD ${ }^{1}$, RICHARD S. SMITH ${ }^{1,2}$ and SIMON W.M. JOHN*,1,2,3 \\ ${ }^{1}$ The Jackson Laboratory, ${ }^{2}$ The Howard Hughes Medical Institute, Bar Harbor, Maine and ${ }^{3}$ Department of Ophthalmology, \\ Tufts University School of Medicine, Boston, Massachusetts. USA
}

\begin{abstract}
Development of the ocular anterior segment involves a series of inductive interactions between neural ectoderm, surface ectoderm and periocular mesenchyme. The timing of these events is well established but less is known about the molecular mechanisms involved. Various genes that participate in these processes have been identified. As the roles of more genes are determined, developmental pathways and networks will emerge. Here, we focus on recent advances made using mouse models. We summarize key morphological events in formation of anterior chamber structures, including the aqueous humor drainage structures that are involved in intraocular pressure (IOP) regulation and glaucoma. We discuss the developmental roles of genes that associate with abnormal anterior segment development and elevated IOP or glaucoma (including Bmp4, Cyp1b1, Foxc1, Foxc2, Pitx2, Lmx1b and Tyr) and how some of these genes may fit into developmental networks.
\end{abstract}

KEY WORDS: ocular development, glaucoma, trabecular meshwork, dysgenesis

\section{Anterior segment dysgenesis and glaucoma}

Ocular anterior segment dysgenesis (ASD) is a genetically heterogeneous group of developmental disorders (Gould and John 2002). Studying ocular development provides insight about how mis-regulated developmental processes lead to ASD. Various terms exist for human ASD including Axenfeld's anomaly, Rieger's anomaly, Peters' anomaly, aniridia, iris hypoplasia and iridogoniodysgenesis. However, clinical findings overlap within families and mutations in the same gene can cause a range of phenotypes. Considering human and mouse data, it is clear that ASD is a complex, continuous spectrum of disorders (Waring et al., 1975, Shields et al., 1985, Alward 2000, Gould and John 2002).

Glaucoma is a leading cause of blindness estimated to affect 70 million people (Thylefors and Negrel 1994, Quigley 1996). A major risk factor for glaucoma is elevated IOP. Patients with ASD often have malformations of the tissues responsible for IOP regulation and aqueous humor drainage. They frequently develop elevated IOP, putting them at risk for developing glaucoma. Developmental glaucomas, secondary to morphological malformations of the anterior segment are relatively rare forms of glaucoma. Importantly however, developmental abnormalities of the ocular drainage structures are not always clinically detectable and abnormal development may affect the metabolism and function of the drainage structures without disturbing morphology.
Therefore, mutations in developmental genes may contribute to glaucoma more frequently than accepted, possibly contributing to common forms such as primary open angle glaucoma, which do not present with obvious developmental abnormalities.

\section{Morphogenesis}

\section{Tissue derivations}

The anterior segment consists of the cornea, iris, lens, ciliary body and ocular drainage structures (trabecular meshwork and Schlemm's canal). The drainage structures are located at the iridocorneal angle where the iris and cornea meet. This region is also known as the corneoscleral transition zone as the ocular wall transitions from cornea to sclera at this location. The anterior segment also includes the anterior chamber (space between the iris and cornea) and posterior chamber (space between iris and lens). These structures are formed by coordination of events involving induction and differentiation of three main tissue types: surface ectoderm, neural ectoderm and periocular mesenchyme (Fig. 1). Much of what we know about these events comes from

Abbreviations used in this paper: ASD, anterior segment dysgenesis; BMP, bone morphogenetic protein; ECM, extracellular matrix; FOX, forkhead box; GDF, growth and diferentiation factor; IOP, intraocular pressure; TH, tyrosine hydroxylase; Tyr, tyrosinase gene. 
A

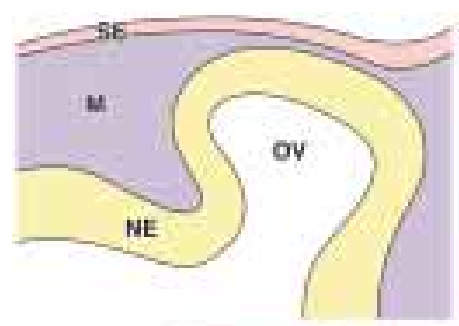

B
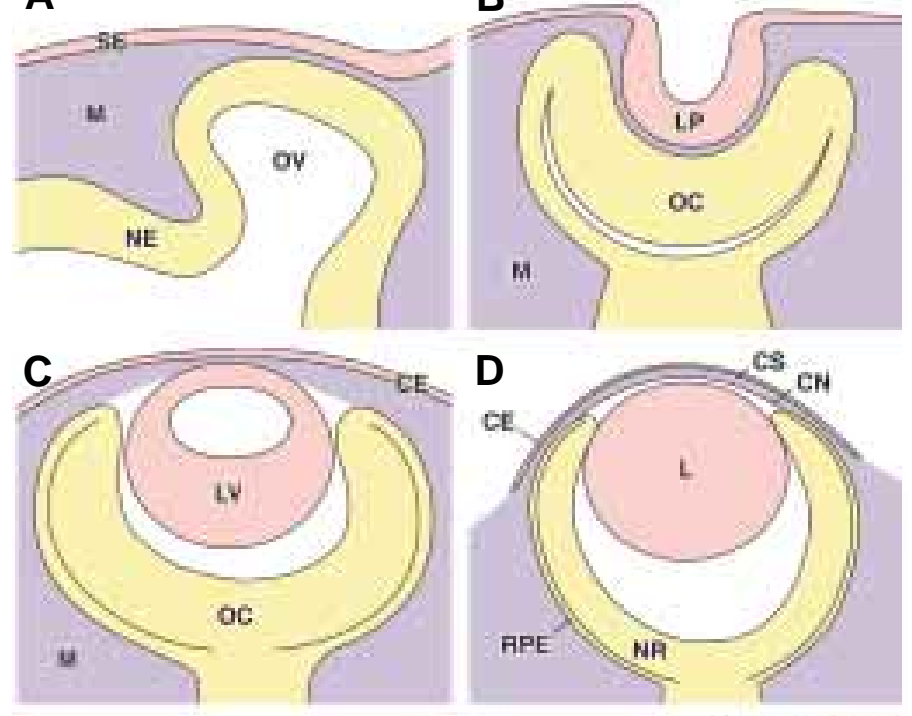

E

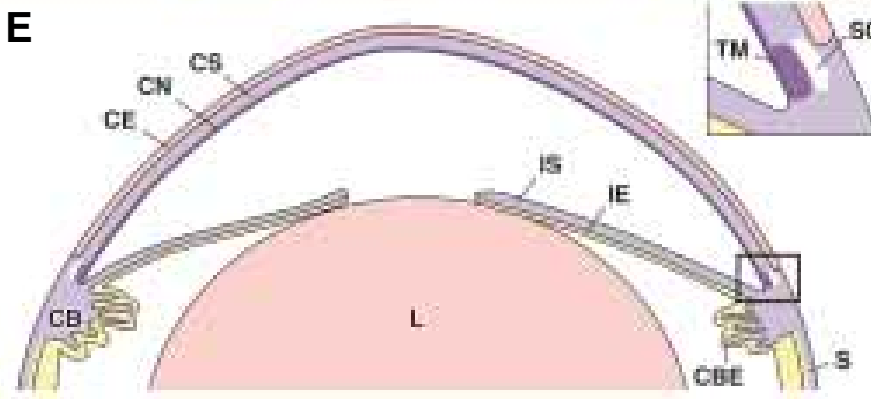

Fig. 1. Tissue derivations of developing ocular structures. A color scheme is used to represent tissue derivations. For clarity, periocular mesenchyme derived tissues are represented by two shades of purple. (A) Neural ectoderm ( $N E$, yellow) of the emerging optic vesicle (OV) moves through periocular mesenchyme ( $M$, purple) until it reaches the surface ectoderm (SE, pink). (B) The surface ectoderm thickens and invaginates to form the lens pit (LP) as the optic vesicle forms the optic cup (OC). (C) The lens vesicle ( $L V$ ) detaches from the surface ectoderm. The surface ectoderm becomes the epithelial layer of the future cornea (CE). Periocularmesenchyme migrates between the surface ectoderm of the corneal epithelium and the lens vesicle. (D) Lens fibers fill the lens vesicle. Mesenchyme that has migrated between the corneal epithelium and the lens forms corneal stroma (CS) and corneal endothelium (CN). Neural ectoderm in the inner layer of the optic cup will form neural retina (NR) and the outer layer will form retinal pigmented epithelium (RPE). (E) In the mature eye, the anterior rim of the optic cup has moved centrally and forms the epithelia of the iris (IE) and ciliary body (CBE). Iris stroma (IS), stroma and muscle of the ciliary body (CB), trabecular meshwork (TM) and Schlemm's canal (SC) are formed from periocular mesenchyme. Condensed periocular mesenchyme forms the sclera (S) and surrounds the posterior of the eye.

experiments with model organisms including frog, chick, rat and mouse (Jacobson and Sater 1988, Furuta and Hogan 1998, Beebe and Coats 2000, Fuhrmann et al., 2000). In this review, we concentrate on recent advances using the mouse.

Through the course of ocular development, the surface ectoderm will form the corneal epithelium and lens while the neural ectoderm derivatives will form the retina and epithelia of both the iris and ciliary body (Kaufman 1995). The corneal stroma, corneal endothelium, sclera, iris stroma, ciliary muscle, ciliary stroma and trabecular meshwork are all derived from periocular mesenchyme. Schlemm's canal forms by remodeling of vasculature in the corneoscleral transition zone (Hamanaka et al., 1992, Smith et al., 2001) and is likely derived from periocular mesenchyme. Thus the periocular mesenchyme, which consists of neural crest and cranial paraxial mesoderm derived cells, contributes extensively to the ocular anterior segment (Noden 1975, Johnston et al., 1979, Trainor and Tam 1995). Defects of periocular mesenchyme including patterning, migration or differentiation may contribute to ASD and glaucoma (Kupfer and Kaiser-Kupfer 1978, Kupfer and KaiserKupfer 1979, Kaiser-Kupfer 1989, Tripathi and Tripathi 1989).

\section{Prenatal development}

Before focusing on anterior segment development, we will briefly discuss early events of specification and morphogenesis of the optic vesicle and optic cup (for more detailed review see Freund et al., 1996; Chow and Lang 2001). Specification of the eye field in neural ectoderm and lens induction in surface ectoderm are primary events in ocular development (Zuber et al., 2003). Mutations in genes involved in these early events often result in anophthalmia (for examples, see Hogan et al., 1986; Hill et al., 1991; Mathers etal., 1997; Dattani etal., 1998). In the mouse, the eye field is initially specified as a dorsal strip on the anterior part of the forebrain around embryonic day (E) 8.5 (for review see Chow and Lang 2001). Soon after, the field is restricted to a lateral position where the optic pits form on the inner surface of the cephalic neural folds (Pei and Rhodin 1970, Kaufman 1995). By E9.0, the neural folds oppose each other and the optic pits deepen becoming the optic vesicles. Each optic vesicle moves through a layer of mesenchyme until it reaches the surface ectoderm at about E9.5 (Pei and Rhodin 1970). The interaction of the optic vesicle with surface ectoderm induces formation of the lens placode in the surface ectoderm and the retinal placode in the neural ectoderm. By E10.5, cellular proliferation in the lens placode contributes to formation of the lens pit and then the lens vesicle. Invagination of the lens pit coincides with folding of the neural ectoderm, which forms the optic cup (Fig. 1). The lens vesicle remains connected to surface ectoderm by the lens stalk until E11.0 when it detaches (Pei and Rhodin 1970, Kaufman 1995, Grimm et al., 1998). The optic cup gives rise to the future neural retina and retinal pigment epithelium. The optic cup also contributes to the anterior segment, as the anterior rim of the optic cup will become the epithelium of the iris and ciliary body.

By E12.5, the developing corneal epithelium consists of one to two cell layers of surface ectoderm that rest on a basal lamina (Fig. 2A). Over the next two days, migration of periocular mesenchyme between the corneal epithelium and anterior lens epithelium establishes the presumptive corneal stroma and presumptive corneal endothelium (Fig. 2 A,B) (Pei and Rhodin 1970, Haustein 1983). After migration, the mesenchyme of the posterior cornea begins differentiating to form corneal endothelial cells and keratocytes (Pei and Rhodin 1970, Haustein 1983).

By E14.5-15.5, the corneal endothelium is present and the anterior chamber first appears as a small space (Fig. 2B). Development of a functional corneal endothelium is proposed to be a prerequisite for formation of the anterior chamber (Kidson et al., 1999, Reneker et al., 2000). The anterior rim of the optic cup, which will form the iris and ciliary epithelia, is pigmented and 


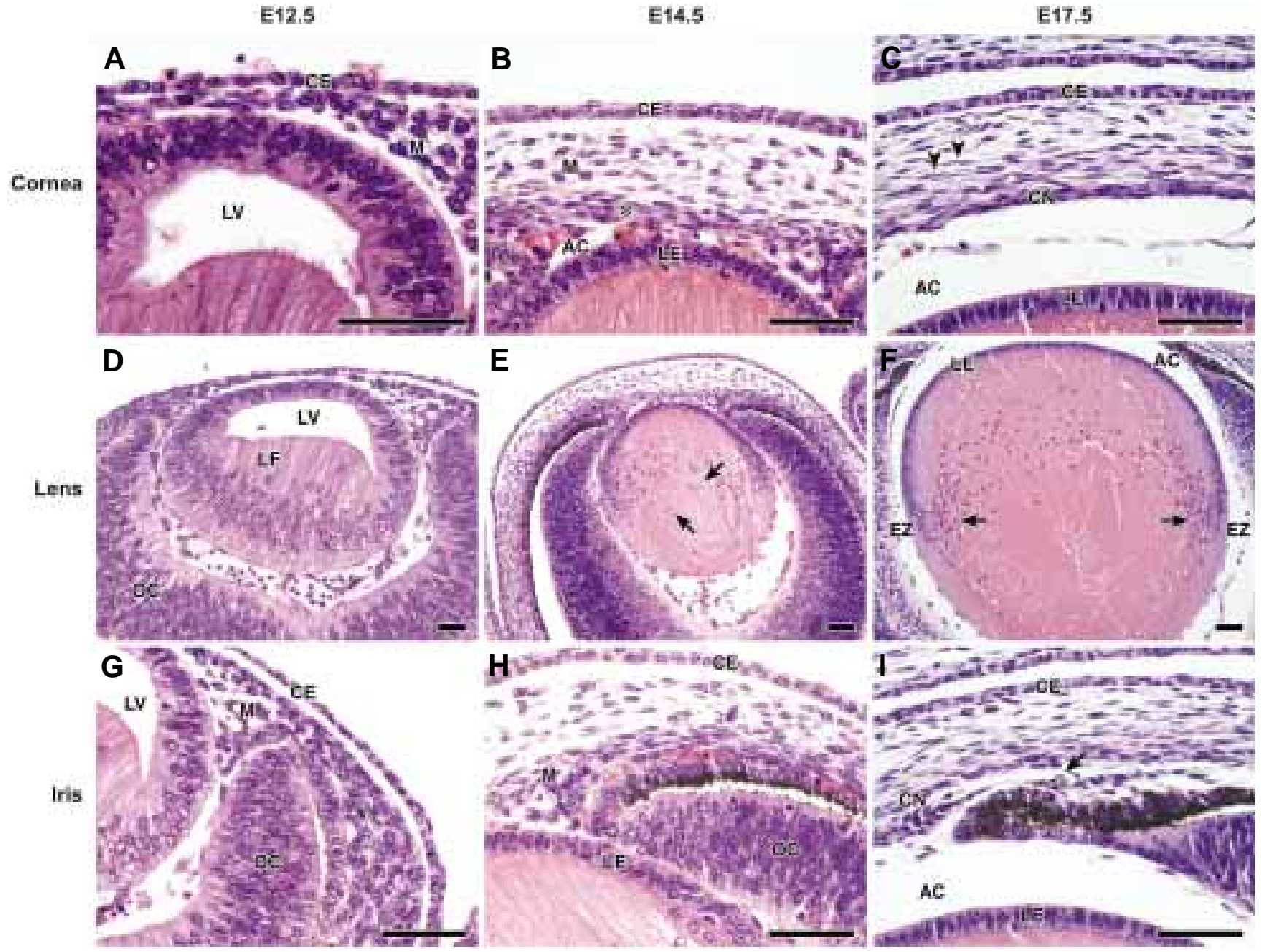

Fig. 2. Prenatal development of cornea, lens and iris. All analyses were performed using C57BL/6J mice. Hemotoxylin and eosin stained sections of eyes at indicated ages. (A-C) Cornea. (A) At E12.5, the corneal epithelium (CE) is 1-2 cells thick. Mesenchyme (M) has started to migrate between the corneal epithelium and the lens vesicle (LV). (B) At E14.5, the corneal epithelium is two cell layers resting on a basal lamina. A thick presumptive corneal stroma has formed from migrating mesenchyme. The posterior mesenchyme has started to condense $\left({ }^{*}\right)$ and form corneal endothelium. The anterior chamber (AC) first appears as a small space above the lens epithelium (LE). (C) At E17.5, differentiating keratocytes become flattened (arrowheads), especially near the endothelium (CN). Extracellular matrix and keratocytes give the stroma a lamellar appearance. The anterior chamber is well established. (D-F) Lens. (D) At E12.5, the cavity of the lens vesicle (LV) is partially filled with elongating primary lens fibers (LF). (E) By E14.5, the primary lens fibers have filled the lens vesicle. Nuclei of the lens fibers are near the center of the lens and become translucent (arrows). (F) At E17.5, the emergence of nuclei of secondary lens fibers (arrows) can be seen near the equatorial zone (EZ). (G-I) Iris. (G) At E12.5, the periocular mesenchyme is migrating into the eye at the rim of the optic cup (OC). It is not possible to distinguish the mesenchyme of the presumptive cornea from that of the iris. (H) By E14.5, the anterior rim of the optic cup is extending anteriorly and the mesenchyme (M) adjacent to the optic cup is condensed. (I) By E17.5, the presumptive iris stroma can be identified and its mesenchyme synthesizes pigment (arrow). The developing iris stroma is bordered anteriorly by the corneal endothelium (CN) and posteriorly by the anterior optic cup that will become the iris pigment epithelium. Panel D is reproduced with permission from Smith et al., (Smith et al., 2001). All other panels are previously unpublished data. Scale bars represent 50 microns.

begins to extend anteriorly and centrally (compare Fig. $2 \mathrm{G}, \mathrm{H}$ ). This provides a base for the periocular mesenchyme that will form the iris stroma and ciliary body stroma. Primary lens fibers fill the lens vesicle and their nuclei arrange near the center of the lens (Fig. 2E). By E16.5, the anterior chamber is formed and the presumptive iris stroma is no longer apposed to the cornea (Fig. 2I). The number of keratocytes in the corneal stroma steadily increases in number until it plateaus at E16.5. By E17.5, the corneal stroma takes on a lamellar arrangement (Fig. 2C).
Secondary lens fibers are produced at the equatorial zone of the lens (Fig. 2F).

\section{Postnatal development}

Although many studies have detailed prenatal ocular development, few reports document postnatal development. Significant development of the anterior chamber structures occurs in the postnatal period (Smith et al., 2001, Baulmann et al., 2002). This is especially true for the drainage structures that affect IOP and glaucoma. 

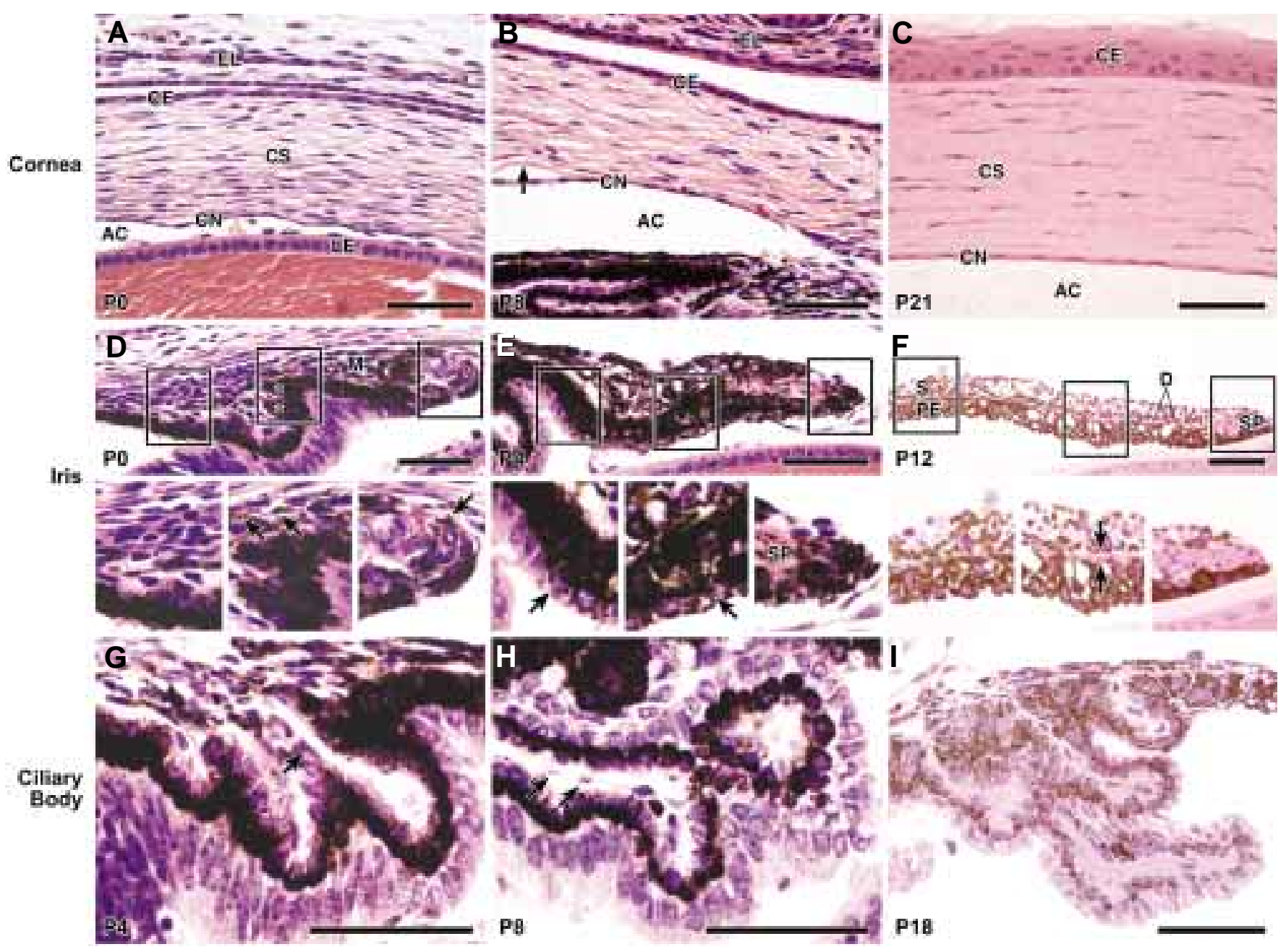

Fig. 3. Postnatal development of cornea, iris and ciliary body. All analyses were performed on C57BL/6J mice. (A-C) Cornea. (A) At PO, the corneal epithelium (CE) is two cell layers thick and covered by eyelid (EL). The corneal stroma (CS) has a lamellar arrangement of extracellular matrix and flattened keratocytes and the corneal endothelium (CN) is present. The anterior chamber $(A C)$ is the space defined by the corneal endothelium and lens epithelium (LE). (B) By P8, the corneal stroma is less cellular. Descemet's membrane (arrow) is clearly visible in an area of artifactual separation from the corneal endothelium (CN). (C) By P21, the cornea is mature. The eyelids are open and the corneal epithelium is five cell layers thick. (D-F) Iris. (D) Dense mesenchyme (M) is present on the anterior of the developing iris and will give rise to the iris stroma. Small folds in the pigment epithelium (asterisks and middle inset) indicate early morphogenesis of ciliary processes. The cells of the presumptive iris stroma begin to synthesize pigment (arrows in insets) and this distinguishes them from the cells that give rise to the trabecular meshwork (left inset). (E) By P4, the iris has extended centrally. The posterior layer of iris pigment epithelium is only slightly pigmented peripherally (arrow in left inset) but more so centrally (arrow in middle inset). The entire anterior layer of pigmented epithelium is already pigmented. The stroma is also pigmented by this time (middle inset) and the iris sphincter muscle (SP) is present (right inset). (F) At P12.5 the iris is mature with a robust stroma (S) that is separated from the bi-layered pigment epithelium (PE) by a thin dilator muscle (D) (between arrows in inset). The sphincter muscle is located at the pupilary margin. (G-I) Ciliary Body. (G) Compared to the PO ciliary body shown in (D), the ciliary body at P4 has well formed ciliary processes. Endothelial cells are present indicating that the vascular core is being established (arrow). (H) By P8, the ciliary body is completely developed with a vascular core (arrows). (I) Lower magnification image of a mature ciliary body at P18. All panels are of previously unpublished data. Scale bars represent 50 microns.

At birth, the corneal epithelium is one to two cells thick. The corneal stroma is filled with keratocytes surrounded by extracellular matrix (ECM) and the corneal endothelium is clearly defined (Fig. $3 \mathrm{~A}$ ). Descemet's membrane (a specialized basal lamina of the corneal endothelium) is still not evident by light microscopy but can be detected by electron microscopy (Kidson et al., 1999, Smith et al., 2001). The mesenchyme of the presumptive iris stroma begins to synthesize pigment distinguishing it from the trabecular meshwork mesenchyme (Fig. 3D middle inset compared to left inset). Future ciliary processes are visible as slight folds in the ciliary pigment epithelium (Fig. 3D). By postnatal day (P) 2 to $\mathrm{P} 4$, there is a decrease in cellularity of the corneal stroma. The iris and ciliary body are now clearly distinguishable from each other. There are prominent ciliary folds (Fig. 3G), the iris stroma is darkly pigmented and there is clear evidence of iris sphincter muscle development (Fig. 3E). The mesenchyme of the presumptive trabecular meshwork is densely packed (Fig. 4A) (Smith et al., 2001). By P6-P8, Descemet's membrane is distinct from the corneal stroma (Fig. 3B). The iris stroma, pigment epithelium, dilator muscle and sphincter muscle are mature by P8-P10 (Fig. 
3F). The processes of the ciliary body are completely developed and have a vascular core, but ciliary muscle fibers are not yet present (Fig. 3H).

At this stage, the presumptive trabecular meshwork is a mass of mesenchymal cells in the iridocorneal angle. To allow aqueous humor drainage, this mesenchymal mass remodels (see below) to form a functional trabecular meshwork (Smith et al., 2001). A major component of the functional trabecular meshwork is ECM organized into a network of beams that are covered by trabecular cells. The ECM includes collagen, laminin, elastin, fibronectin and vitronectin (Yue 1996). Intertrabecular spaces, between the beams of the functioning meshwork, allow aqueous humor to flow to Schlemm's canal. The aqueous humor passes through the endothelial wall of Schlemm's canal in drainage structures known as giant vacuoles. The lumen of Schlemm's canal connects to the venous system through collector channels. Abnormal development of these iridocorneal angle structures can lead to elevated IOP and glaucoma.

In the mouse, the process of forming the functional trabecular meshwork from the mesenchymal mass involves morphogenesis of closely packed beams followed by tissue remodeling to open up the intertrabecular spaces, without cell death or atrophy (Smith et al., 2001). At P10, the mesenchymal cells align parallel to the cornea. Between P10 and P14 trabecular beams appear but are still closely apposed (Fig. 4 B,C) (Smith et al., 2001, Baulmann et al., 2002). Ciliary muscle fibers are observed and Schlemm's canal appears as a small lumen lined with endothelial cells (Fig. 4C). Intertrabecular spaces first form between the trabecular
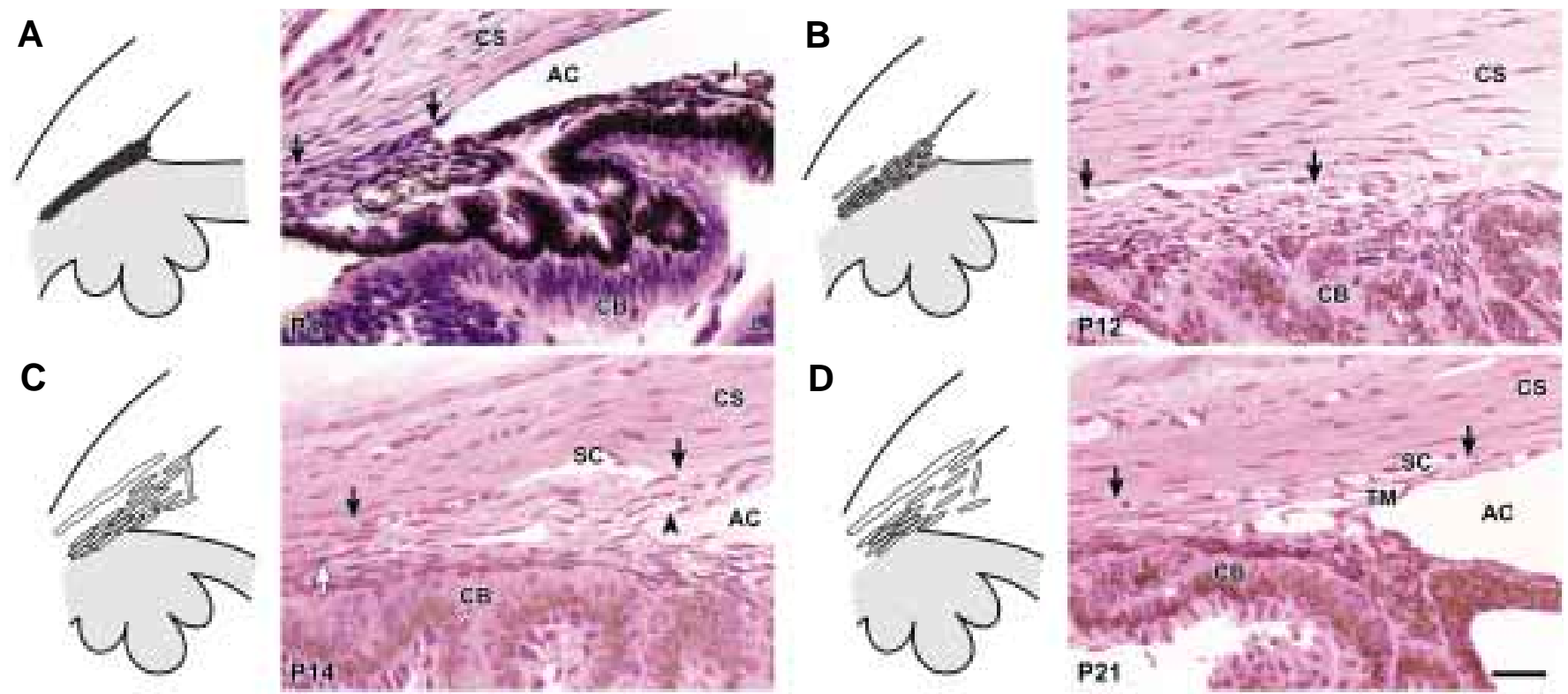

Fig. 4. Postnatal development of the iridocorneal angle. The diagrams represent the relative developmental states of trabecular meshwork and Schlemm's canal in C57BL/6J mice at each stage. They are based on analysis of multiple mice and are not direct representations of the adjacent histologic images. The diagrams indicate the enlargement of Schlemm's canal and opening of aqueous humor drainage channels (intratrabecular spaces) in the trabecular meshwork. (A) At P4, the anlage of the trabecular meshwork is recognizable as condensed mesenchyme (arrows) between the corneal stroma (CS) and ciliary body (CB). AC, anterior chamber and I, iris. (B) By P12, trabecular meshwork cells have differentiated and trabecular beams are present but are still packed close together. Schlemm's canal is present by this age (between arrows). (C) By P14, trabecular beams nearest the anterior chamber begin to separate as intertrabecular spaces appear (arrowhead) but aqueous humor access to Schlemm's canal (SC, between arrows) is still restricted. Ciliary muscle fibers are present (open arrow). (D) The angle continues to remodel with more intratrabecular spaces forming between the trabecular beams. At P21, the major morphogenesis is complete with only minor remodeling occurring afterwards (up to approximately P35). Adapted with permission from (Smith et al., 2001). Scale bars represent 50 microns.

beams nearest the anterior chamber. As the channels between the trabecular beams form, aqueous humor can enter the drainage (tow towards Schlemm's canal. Abundant giant developed except for minor remodeling that increases the extent of the intertrabecular spaces (Fig. 4D) (Smith et al., 2001).

\section{Molecular development}

Although the developmental networks are largely undefined, some of the molecules and pathways contributing to anterior development are known. We now discuss anterior segment development and are associated with IOP and glaucoma. We include the recently identified role of tyrosinase/Ldopa, since it modifies phenotypes in mice with mutations in the genes known to cause ASD. We discuss recurring themes with multiple genes and suggest potential interactions between the different genes and pathways.

\section{Transforming Growth Factor Beta Super-Family}

The TGF $\beta$ super-family of secreted signaling molecules influences a spectrum of biological processes including pattern bone morphogenesis and wound repair (Graham et al., 1994, Hogan 1996, Hogan 1999, Mabie et al., 1999). Abnormal TGF $\beta$ signaling contributes to a wide variety of disease processes

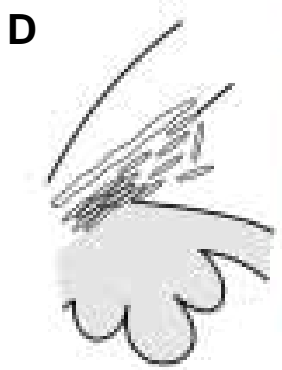


(Miyazono et al., 2001). The TGF $\beta$ super-family is divided into two similar but separate branches: the BMP/GDF (bone morphogenetic protein/growth and differentiation factor) branch and the TGF $\beta$ / activin/nodal branch. Each branch works through extracellular ligand binding to a membrane bound receptor complex consisting of Type I and Type II serine/threonine kinase receptors. Ligand binding initiates a cytoplasmic signal cascade that activates SMAD (also called MADH) proteins. Activated SMAD proteins enter the nucleus where they associate with transcription factors and participate in transcriptional regulation of target genes (Cho and Blitz 1998, Chang et al., 2001b, Miyazono et al., 2001, Balemans and Van Hul 2002).

Multiple TGF $\beta$ super-family pathway members are important in ocular development. Bmp4 is expressed in the distal portion of the emerging optic vesicle and in the overlying surface ectoderm. Expression becomes restricted to the dorsal distal tip of the optic vesicle at the site of contact with the surface ectoderm and later to the dorsal rim of the optic cup (Furuta and Hogan 1998). Postnatally, $B m p 4$ is expressed in the pigmented epithelia of the iris, ciliary body and the retina that all derive from the optic cup (Chang et al., 2001a). Two BMP4 receptors, BMPR1A and BMPR1B are present in the developing eye. Bmprla is expressed throughout most ocular tissues up to at least E11.5. Bmpr1b is expressed in head mesenchyme as early as E9.5 (Furuta and Hogan 1998).

Completely Bmp4 deficient mice (homozygous mutant, Bmp4$\left.{ }^{-}\right)$are not viable and do not develop eyes due to the absence of lens induction (Furuta and Hogan 1998). Partially Bmp4 deficient mice (heterozygous mutant, Bmp4 ${ }^{+-}$) develop eyes but often have severe ASD (Chang et al., 2001a). Although the phenotype is variable and dependent on genetic background, all $B \mathrm{mp} 4^{+-}$mice have some degree of ASD. All anterior segment tissues are affected including lens, iris, cornea, trabecular meshwork and Schlemm's canal. The trabecular meshwork is hypoplastic, compressed, has a reduction in number of trabecular beams and has less ECM (Chang et al., 2001a). ASD in $\mathrm{Bmp4}^{+/-}$mice is similar to ASD in human patients.

Molecular details of how BMP4 influences ocular development are starting to be revealed. Bmp4 is expressed in the distal optic vesicle and has a receptor ubiquitously expressed in ocular tissues. Complete BMP4 deficiency results in a loss of Sox2expression in the surface ectoderm and loss of Msx2expression in the distal optic vesicle (Furuta and Hogan 1998). SOX2 is required for lens induction and mutations in SOX2 have recently been reported in human patients with anophthalmia (Fantes et al., 2003). It is possible that BMP4 from the optic vesicle binds BMPR1A in surface ectoderm and induces Sox2 expression via SMAD transcriptional complexes. Alternatively or additionally, Msx2in the optic vesicle may be the target of BMP4 signaling which then plays a role in supplying a second signal for Sox2 expression. Either of these paradigms would explain the loss of both Sox2 expression and lens induction in the absence of BMP4 (Furuta and Hogan 1998).

Even though there are no known targets for BMP4 in the periocular mesenchyme, mesenchyme-derived tissues are malformed in Bmp4 $4^{+/-}$mice and BMP4 receptors are present in mesenchyme. Therefore, it is possible that BMP4 has a direct effect on the mesenchyme. In $B m p 4^{+/-}$mice, the mesenchymederived trabecular meshwork has profound ECM deficiencies. ECM is known to be developmentally important for many tissues and provides cues for cellular metabolism and various developmental processes such as migration and differentiation (Adams and Watt 1993, Lin and Bissell 1993, Perris 1997). Thus, BMP4 may influence trabecular meshwork morphogenesis by regulating $\mathrm{ECM}$ features (including composition and signaling) that are important for mesenchymal migration, differentiation and/or remodeling.

TGF $\beta 2$ is another signaling ligand involved in anterior segment development. The corneas of TGF $2 \%$ mice have reduced accumulation of ECM and are thin with densely packed keratocytes. The corneal endothelium fails to differentiate and an anterior chamber never forms (Saika etal., 2001). The trabecular meshwork in these mice has not been closely studied. Like BMP4, the relevant downstream targets of TGF $\beta 2$ signaling are not known. However, the BMP 4 and TGF $\beta 2$ pathways do converge and overlap (Miyazono et al., 2001). Given the convergence of the pathways and the paucity of ECM in the eyes of $\mathrm{Bmp4}^{+/}$and $\mathrm{Tgfb}^{\%}$ mice, it is possible that ECM components are important downstream targets of both of these signaling molecules.

A key step in regulation of TGF $\beta$ super-family signaling is inhibitory binding of the ligand by extracellular antagonists such as noggin (NOG) (Cho and Blitz 1998, Balemans and Van Hul 2002). Transgenic over-expression of Nog demonstrates the importance of BMP signaling in the development of the ciliary body. Ectopic, lens-specific expression of Nog, presumed to antagonize BMP4 and BMP7, decreases levels of activated SMAD1 in lens epithelium, ciliary epithelium, corneal epithelium and mesenchymal cells (Zhao et al., 2002). These data show that SMAD1 is an important mediator of BMP signaling in ciliary body development. Furthermore, inhibiting BMP signaling with NOG significantly down regulates expression of the downstream targets $M s \times 1$ and $O t \times 1$ in the ciliary epithelium. Otx1 is necessary for development of the ciliary body (Acampora et al., 1996). By re-introducing transgenic Bmp7 (presumably re-establishing a ratio of ligand/antagonist) normal ciliary body development is restored (Zhao et al., 2002).

It is clear that members of the TGF $\beta$ signaling super-family pathway are important for normal ocular development. Therefore, any genes that influence the balance of TGF $\beta /$ BMP signaling are candidates to affect anterior segment development and glaucoma phenotypes.

\section{PAX6}

PAX6 is a transcription factor with paired-class and homeobox DNA binding domains. In neural ectoderm derivatives, Pax6 is expressed in the distal optic vesicle, rim of the optic cup and then in the epithelia of iris and ciliary body, which arise from the rim of the optic cup. Pax6expression in surface ectoderm is broad at E8.5 but becomes restricted to the lens placode by E9.5. It is retained throughout development in ocular tissues derived from surface ectoderm (Walther and Gruss 1991, Grindley et al., 1995, Koroma et al., 1997, Baulmann et al., 2002). Pax6 is also expressed in the developing iris stroma, ciliary stroma and trabecular meshwork, consistent with a regulatory function during the morphogenesis of these mesenchymal derived tissues (Baulmann et al., 2002).

The small eye mutant mouse has a null allele of Pax6 (Pax6 ${ }^{\text {Sey }}$ ) (Hill et al., 1991). Homozygous Pax6 Seylsey mice, have morphological abnormalities of the optic vesicle and lens induction fails (Hogan et al., 1986). Mice heterozygous for the Pax fm1Pgr $^{\text {If }}$ targeted null allele have ocular defects including small eyes, small 
anterior chambers, corneal haze, iris hypoplasia, iridocorneal adhesions, dysgenesis of the trabecular meshwork and absence of Schlemm's canal (Baulmann etal., 2002). The trabecular meshwork is hypoplastic and undifferentiated. Null mutations or duplications of $P A X G$ can cause anterior segment dysgenesis indicating the importance of PAX6 dosage for normal development (Ton et al., 1991, Jordan et al., 1992, Hanson et al., 1993, Glaser et al., 1994, Hanson et al., 1994).

There is conservation of PAX6 regulated gene function between flies and vertebrates (Halder etal., 1995). Many of the same genes and interactions are conserved between flies and vertebrates (Oliver et al., 1995, Pignoni et al., 1997, Xu et al., 1997, Heanue et al., 1999, Kozmik et al., 1999, Xu et al., 1999a, Xu et al., 1999b, Heanue et al., 2002, Hsieh et al., 2002). Therefore, mammalian orthologues of the fly genes are good candidates to participate in anterior segment development and may contribute to ASD and glaucoma. The Drosophila Pax6paralogues eyeless (ey) and twin of eyeless (toy) participate in a complex regulatory hierarchy of gene expression. During ocular development in Drosophila, they regulate the genes eyes absent (eya), sine oculus (so) and dachshund (dac). Mutations in a human eyes absent orthologue EYA1 associate with anterior segment malformations (Azuma et al., 2000). The genetic interactions within this pathway have been the subject of considerable study in flies and vertebrates (for review see Treisman 1999; Wawersik and Maas 2000; Pichaud and Desplan 2002; van Heyningen and Williamson 2002).

\section{FOXC1 and FOXC2}

FOXC1 (forkhead box $\mathrm{C} 1$ ) is a transcription factor with a forkhead/winged-helix DNA binding domain. In the developing eye, Foxc1 is primarily expressed in the periocular mesenchyme and mesenchymal cells that have migrated into the eye (Kume et al., 1998, Kidson et al., 1999). At E12.5, the presumptive cornea between the surface ectoderm and the lens no longer expresses Foxc1. By E16.5, expression of Foxc1 is further restricted to the region of the future trabecular meshwork (Kidson et al., 1999). Fox $1^{-1}$ mice die at birth with multiple congenital abnormalities including skeletal defects and hydrocephalus (Kume et al., 1998, Hong et al., 1999). They also have severe anterior segment developmental defects. In corneas of Fox $1 \%$ mice the epithelium is thickened, the stroma is disorganized and there is no differentiation of the endothelium. The lens fails to separate from the cornea and as a result there is a complete absence of the ocular anterior chamber (Kidson et al., 1999).

Foxc1 ${ }^{\text {t- }}$ mice are viable and have milder anterior segment defects than Foxc1-- mice (Hong et al., 1999, Smith et al., 2000). Development of periocular mesenchyme derived tissues is abnormal in Foxc1 ${ }^{+/}$mice. Abnormalities include iris malformations, iridocorneal adhesions and corneal opacity. Angle malformations include small or absent Schlemm's canal and hypoplastic, compressed trabecular meshwork. Abnormal iridocorneal angle structures have a paucity of ECM including collagen and elastic tissue and cells that have the appearance of undifferentiated precursor cells. Even though clinically obvious iris and corneal abnormalities do not occur in Foxc1 ${ }^{+/-}$mice on some genetic backgrounds, all mice have histologically detectable malformations of the trabecular meshwork and Schlemm's canal. This indicates that genetic modifiers have a differential influence on iris and corneal development compared to iridocorneal angle development and it suggests that iridocorneal angle development may be more sensitive to levels of FOXC1.

FOXC2 is a forkhead/winged-helix transcription factor with strong homology to FOXC1. FoxC1 and FoxC2 have largely overlapping expression patterns including similar expression in the periocular mesenchyme and in tissues derived from periocular mesenchyme (Winnier et al., 1997, Hiemisch et al., 1998). These genes have overlapping function, at least in the developing heart (Winnier et al., 1999). FOXC2 affects ocular development in a very similar fashion to FOXC1 suggesting that they also have overlapping function in the developing eye (Smith et al., 2000).

All double heterozygous (FoxC1 ${ }^{+/-}$FoxC2 ${ }^{+/}$) mice have malformations of the ciliary body not usually seen in mice heterozygous for either mutant gene alone (Smith et al., 2000). The fact that a phenotype that is not present in either single heterozygote is revealed in double heterozygotes strongly supports overlapping functions of FOXC1 and FOXC2 in the developing eye. It also suggests that the ciliary body requires a certain threshold level of FOXC transcription factors for normal development (total FOXC1 and FOXC2) that often is not maintained in double heterozygotes.

Patients with mutations in FOXC1 have a spectrum of ASD and glaucoma phenotypes (Mears et al., 1998, Nishimura et al., 1998, Mirzayans et al., 2000, Nishimura et al., 2001, Honkanen et al., 2003). Similar to PAX6, normal development is very sensitive to FOXC1 dosage and both duplications or deletions can cause ASD (Kume et al., 1998, Lehmann et al., 2000, Nishimura et al., 2001, Saleem et al., 2001, Saleem et al., 2003a, Saleem et al., 2003b).

No upstream regulators or downstream targets of FOXC1 or FOXC2 are known. Foxc1 and Foxc2have very similar expression patterns and their DNA binding domains are nearly identical. Thus, it is likely that FOXC1 and FOXC2 share at least some downstream target genes. Given the phenotypic similarity of Bmp4, Tgfb2, FoxC1 and FoxC2 mutant mice, it is possible that TGF $\beta$ family members and FOXC transcription factors act in the same pathway. Other members of the winged-helix family of transcription factors are known to facilitate TGF $\beta$ super-family signaling in Xenopus and mouse. FOXH1 (formerly FAST for forkhead activin signal transducer) is a forkhead/winged-helix transcription factor that associates with SMAD proteins activated by the TGF $\beta$ signaling ligand activin (Chen et al., 1996, Chen et al., 1997, Weisberg etal., 1998, Liu et al., 1999, Germain et al., 2000). It is possible that FOXC1 and FOXC2 interact with SMAD proteins to mediate BMP4 (or other TGF $\beta$ super-family ligand) signaling.

Similar to $B \mathrm{mp}^{+/}$and Tgfb $2^{+/}$mutant mice, FoxC1 ${ }^{+/}$and FoxC2 ${ }^{+/}$mutants have major deficiencies of ECM in the iridocorneal angle structures. Additionally, Fox $1^{-1}$ mice have ECM abnormalities in other tissues including the arachnoid layer of the meninges and the prechondrogenic mesenchyme (Kume et al., 1998, Hong et al., 1999). Thus, FOXC1 and FOXC2 may control development by directly or indirectly affecting synthesis and/or metabolism of ECM (Fig. 5).

\section{FOXE3}

A third winged-helix/fork head gene, Foxe 3 is also involved in ocular development. In contrast to mesenchymal expression of Foxc1 and Foxc2, Foxe 3 is expressed in the lens placode, lens pit and anterior lens vesicle before becoming restricted to the anterior lens epithelium (Blixt et al., 2000, Brownell et al., 2000). Mice homozygous for a Foxe3 mutation ( $d y /$ for dysgenetic lens) have 


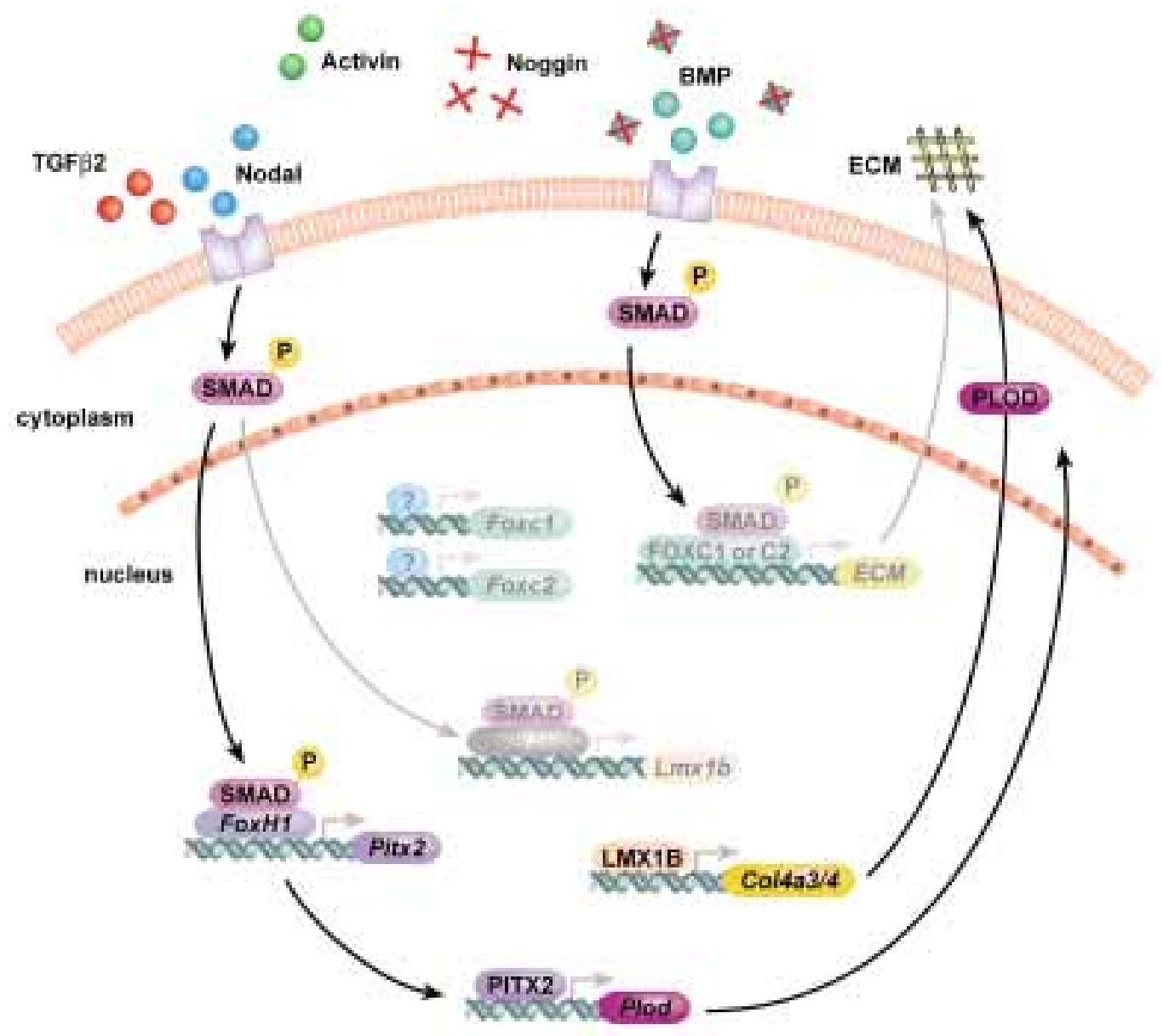

Fig. 5. TGF $\beta$-superfamily/BMP signaling and anterior segment developmental genes. The ways in which known anterior segment developmental genes interact is largely unknown. In an attempt to link the functions of known genes, this figure suggest that TGF $\beta$ superfamily signaling may regulate developmentally important roles of ECM by modulating the expression of genes that are known to affect both anterior segment development and ECM composition/abundance in the eye. Dark arrows indicate steps supported by experiments in various developmental systems. Proposed interactions are depicted as fainter arrow and symbols. TGF $\beta$ signaling ligands (Activin, Nodal, BMPS, TGF $\beta 2$ ) bind transmembrane receptors and activate SMAD proteins by phosphorylation, while Noggin is an antagonist. Phosphorylated SMAD proteins translocate to the nucleus where they associate with DNA binding transcription factors (e.g. FOXH1) to regulate the transcription of target genes. Some of these target genes are known to affect ECM synthesis or modification as described in the text. Others, such as Foxc1, are known to affect ECM abundance and structure but it is not known if this is a direct or indirect effect. Although drawn in a sequential linear sequence, it is possible that these interactions do not occur in the same cell or developing tissue. For example, PITX2 induction by nodal may not occur at the same time or place as PITX2 activation of Plod genes. Similarly the depicted events may not be sequentially dependent. For example, Nodal activation of Pitx2 may not be necessary for Plod activation since Pitx2 may also be regulated by other factors. PLODs hydroxylate lysine residues in collagen that are important for intermolecular crosslinks.

small eyes and persistent adhesion of the anterior lens epithelium to the cornea (Sanyal and Hawkins 1979, Blixt et al., 2000, Brownell et al., 2000). Atrophy of the lens epithelium and vacuolization of the lens body occurs.

Foxe 3acts downstream of Pax6. Homozygous mutant Pax $\sigma^{\text {Sey/ }}$ $\mathrm{Sey}$ mice develop an optic vesicle but fail to induce a lens placode. There is no induction of Foxe 3 in the surface ectoderm of the Pax6 Sey/Sey presumptive lens placode (Brownell et al., 2000). Furthermore, a surface ectoderm specific decrease in Pax6 is sufficient to ablate Foxe3expression (Dimanlig et al., 2001). This suggests that Foxe 3 is directly or indirectly induced by PAX6 within the surface ectoderm rather than Foxe3 responding to PAX6 induced signals from the optic vesicle.

Dosage levels of both PAX6 and FOXE3 are important. Patients heterozygous for mutations in $P A X 6$ or FOXE3 have ASD phenotypes including failure of lens and cornea to separate (Hanson et al., 1994, Semina et al., 2001, Ormestad et al., 2002). Similarly, Foxe $3^{+/ d y} /$ mice have lenticorneal adhesions and swollen, misshaped corneas (Ormestad et al., 2002). Although no downstream targets of FOXE3 are known, it appears to be involved in maintenance of proliferation and inhibition of differentiation. In Foxe $3^{d y / / d y / m i c e, ~ l e n s ~ e p i t h e l i a l ~ c e l l s ~ e x i t ~ f r o m ~ a ~}$ proliferative state and enter a differentiated state followed by apoptosis (Blixt et al., 2000, Brownell et al., 2000).

\section{PITX2}

PITX2 is a paired-like homeodomain transcription factor. During normal ocular development, Pitx2 is expressed in the periocular mesenchyme by E9.5 (Gage et al., 1999). Expression persists in the mesenchyme and in the presumptive corneal stroma at E13.5 (Semina et al., 1996, Lu et al., 1999, Hjalt et al., 2000). By E18.5, Pitx2expression is restricted to the presumptive iris and iridocorneal angle (Hjalt et al., 2000). This expression pattern is very similar to the expression patterns of Foxc1 and Foxc2. Pitx2 ${ }^{-/}$mice die by E15.5 (Lin et al., 1999, Lu et al., 1999). At this stage, Pitx2 ${ }^{-/}$mice have thickened, undifferentiated corneas that do not develop corneal endothelium or anterior chambers (Gage et al., 1999, Lu et al., 1999) similar to the eyes of $\mathrm{Tgfb}^{-/}$or FoxC1\% mice. Similar to humans with PITX2 mutations, Pitx ${ }^{+/-}$mice have variable degrees of ASD (Gage et al., 1999).

Indicating the importance of PITX2 activity levels, both hypomorphic and over-activating alleles of PITX2 cause human 
ASD (Semina et al., 1996, Alward et al., 1998, Kulak et al., 1998, Doward et al., 1999, Kozlowski and Walter 2000, Priston et al., 2001, Phillips 2002). Together with the dosage sensitivity for other transcription factors (discussed above), this demonstrates the importance of a narrow range of activity of various transcription factor for normal anterior segment development and reflects a delicate balance of signaling by interacting pathways.

There is evidence that Pitx 2 is at least partially controlled by TGF $\beta$ super-family signaling. Multiple studies show that TGF $\beta$ super-family member, NODAL, can induce Pitx2expression(Logan et al., 1998, Piedra et al., 1998, Ryan et al., 1998, Yoshioka et al., 1998). Pitx2has a NODAL response element in its promoter that contains binding sites for SMAD-associating transcription factor FOXH1 (Shiratori et al., 2001). Furthermore, mice deficient for NODAL receptor Acvr2b(Oh and Li 1997) have phenotypes very similar to mice deficient for Pitx2(Lin et al., 1999, Lu et al., 1999). PITX2 can also determine expression boundaries of BMP4 and therefore, may interact in a regulatory feedback mechanism (Lu et al., 1999).

Procollagen lysyl hydroxylase $(P / o d)$ genes are potential downstream targets for PITX2. The promoter regions of PLOD1 and Plod2have multiple PITX2 binding sites. PITX2 can bind the promoters in vivoand induce expression of a reporter gene driven by this promoter in vitro (Hjalt et al., 2001). PLOD1 and PLOD2 belong to a family of enzymes responsible for hydroxylating lysine residues in collagens. Hydroxylysine residues provide stability to intermolecular collagen cross-links (Kivirikko and Myllyla 1985). Therefore, disturbances of ECM stability and function may underlie PITX2 phenotypes.

\section{PITX3}

A second paired-like homeodomain transcription factor, PITX3, can also cause ASD. Expression of Pitx 3 is first seen at the late lens placode stage around E9.5. Expression continues in the lens pit and primary lens fibers until E16.5 when it is most strongly expressed in the equatorial zone of the lens (Semina et al., 1998, Semina et al., 2000). A recessive mutation in mice, aphakia (ak), causes a massive reduction of Pitx 3 expression. Pitx $3^{\text {ak/ak }}$ mice have small eyes without lenses. Lens morphogenesis is disrupted at approximately E10.5 (Grimm et al., 1998, Semina et al., 2000). The lens vesicle is filled with abnormal cells and primary lens fibers never develop. The lens never detaches from surface ectoderm and eventually dissolves. Anterior segment development is arrested at this point (Grimm et al., 1998, Semina et al., 2000). Dominant mutations in human $P / T X 3$ can cause ASD including cataracts, corneal opacities and iridocorneal adhesions (Semina et al., 1998).

The mouse aphakia mutation provides insight into the regulation of Pitx 3 expression. Pit $3^{a k}$ is caused by a deletion in the Pitx 3 regulatory region. Within the deletion are the binding sites for transcription factor AP2, alpha (TCFAP2A) and avian musculoaponeurotic fibrosarcoma AS42 oncogene homolog (MAF). TCFAP2A and MAF are transcription factors present in the developing lens at times coincident with Pitx3expression (Yoshida et al., 1997, Ogino and Yasuda 1998, Kawauchi et al., 1999, Kim et al., 1999, West-Mays et al., 1999). Mutations of Tcfap2a or Maf can result in abnormal lens development and ASD consistent with their role in induction of Pitx3 (Kim et al., 1999, West-Mays et al., 1999, Jamieson et al., 2002, Lyon et al., 2003).

\section{LMX1B}

LMX1B is a LIM homeodomain class transcription factor expressed throughout the periocular mesenchyme by E10.5 and in the presumptive cornea until E14.5 (Pressman et al., 2000). At birth, corneal expression is still observed in keratocytes, corneal endothelium and mesenchyme of the presumptive iris, ciliary body and trabecular meshwork. Expression is later maintained in the iris and trabecular meshwork but not in the ciliary body (Pressman et al., 2000).

$L m \times 1 b^{-1-}$ mice have multiple developmental defects including ocular malformations (Chen et al., 1998, Pressman et al., 2000). The first morphological abnormality is observed at E15.5. Corneal keratocytes are less densely packed and there is a reduction in the depth of the anterior chamber. After birth, eyes are small and have significant iris and ciliary body hypoplasia including a lack of ciliary folds in the ciliary epithelium. Lens development appears normal except that cells in the lens epithelium have altered morphology. Homozygous null mice die as neonates precluding analysis of any effects of absence of LMX1B on postnatal anterior segment development including morphogenesis of the trabecular meshwork and Schlemm's canal. Detailed analysis of $L m \times 1 b^{+/-}$mice has not been reported. Mutations in $\angle M X 1 B$ have dominant, pleiotrophic effects and cause nail-patella syndrome (NPS) (Dreyer etal., 1998, McIntosh etal., 1998, Vollrath etal., 1998). In addition to dysplastic nails and hypoplastic patellae, NPS is also associated with nephropathy and glaucoma (Lichter et al., 1997).

Compared to wild type mice, $L m \times 1 b^{-/}$mice have molecular differences by $\mathrm{E} 13.5$, before there are morphological differences. Foxc1 expression is altered by $L m x 1 b$ deficiency. Normally, when periocular mesenchyme cells migrate into the presumptive cornea, Foxc1 expression is turned off and the presumptive corneal cells will start to express keratocan (an ECM molecule) as the keratocytes differentiate. In $2 m \times 1 b^{-/}$mice, there is a persistence of Foxc1 expression in the presumptive cornea and these cells do not express keratocan by E15.5 (Pressman etal., 2000). Thus, LMX1B is not required for the migration of mesenchyme into the presumptive cornea but is necessary for the normal differentiation of these cells.

In addition to keratocan, LMX1B also affects expression of other ECM molecules. $L m \times 1 b^{-/}$mice and some NPS patients have renal defects. These defects involve the loss of two subtypes of type IV collagen, COL4A3 and COL4A4, in the glomerular basement membrane. Col4a3and Col4a4are direct transcriptional targets of LMX1B (Morello et al., 2001). Thus, regulation of ECM may be a major role of LMX1B in ocular development.

\section{CYP1B1}

The Cyp1b1 gene (Cytochrome P450, family 1, subfamily b, polypeptide 1) encodes an enzyme that participates in iridocorneal angle development. In the developing mouse eye, Cyp1b1 is reported to be most highly expressed in the ciliary body after birth (Bejjani et al., 2002). Cyp1b1\% mice are grossly normal, but have focal malformations of the iridocorneal angle (Libby et al., 2003). In affected regions, malformations may include hypoplastic trabecular meshwork, abnormally located basal lamina in the trabecular meshwork and iridocorneal adhesions. Recessive mutations in CYP1B1associate with human congenital glaucoma (Stoilov etal., 1997, Bejjani etal., 1998, Plasilova et al., 1999, Bejjani et al., 2000, Belmouden et al., 2002). Developmental malformations in some children with congenital glaucoma resemble those observed in 

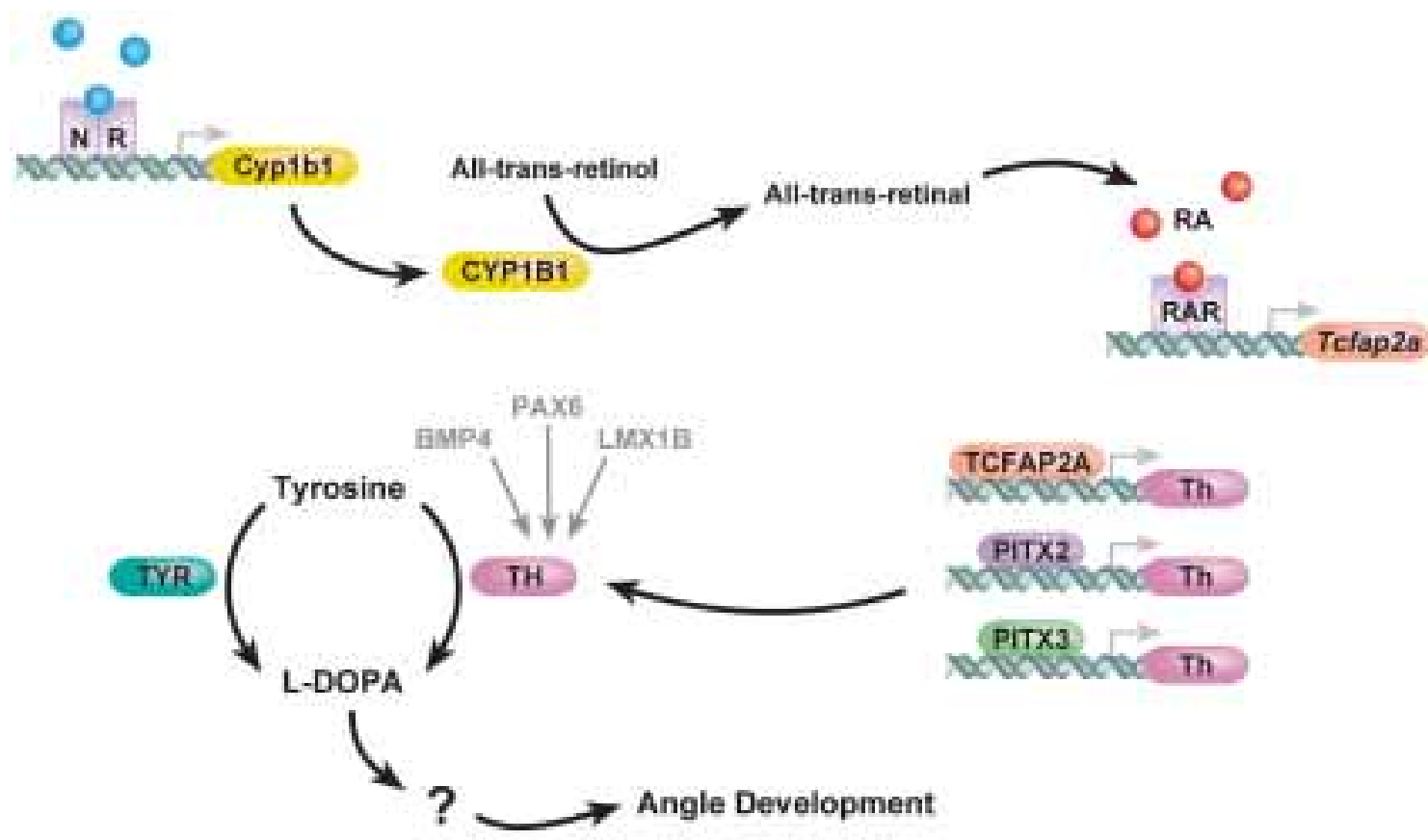

Fig. 6. Multiple genes implicated in anterior segment development and glaucoma may modulate L-dopa levels. Many of the genes implicated in anterior segment dysgenesis, elevated IOP and glaucoma may affect L-dopa levels. Most can be linked to L-dopa through tyrosine hydroxlase (TH, as discussed in the text). The dark arrows represent known direct relationships. TCFAP2, PITX2 and PITX3 can all directly bind to the tyrosine hydroxylase promoter. The fainter arrows and text indicate that the represented genes affects on TH and L-dopa may not be direct. BMP4, PAX6 and LMX1B can promote either tyrosine hydroxylase expression or the number of TH expressing neural crest cells during the development of other tissues, but how they do so is not known. How L-dopa modulates angle development also is not known. It is possible that either L-dopa itself or a catecholamine metabolite(s) of L-Dopa mediates an important signaling event(s).

Cyp1b1\% mice (Allen et al., 1955, Maumenee 1958, Libby et al., 2003).

CYP1B1 belongs to a family of monomeric, mixed function monooxygenases (Sutter etal., 1994). Cyp1b1expression can be induced by aromatic hydrocarbons acting as ligands for a nuclear receptor complex (Denison et al., 1989, Shehin et al., 2000). The receptor complex consists of two basic helix-loop-helix proteins, the aryl hydrocarbon receptor (AHR) and the aryl hydrocarbon nuclear translocator (ARNT) (Reyes et al., 1992, Dolwick et al., 1993). It is hypothesized that CYP1B1 is involved in metabolism of signaling molecules important in ocular development (Sarfarazi and Stoilov 2000). It is possible that in the absence of CYP1B1, a key signaling molecule is not produced/activated or alternatively not degraded/ deactivated. One possibility is that CYP1B1 influences anterior segment development through a mechanism involving retinoic acid signaling. CYP1B1 oxidizes all-trans-retinol to all-trans-retinal which is a rate-limiting step in retinoic acid biosynthesis (Chen et al., 2000). However, the exact role of CYP1B1in ocular development is not known. Cyp $161^{1 /-}$ mice are a valuable tool to address these possibilities.

\section{Tyrosinase modifies anterior segment dysgenesis}

The tyrosinase gene ( $T y r$ ) was recently identified as a modifier of iridocorneal angle defects present in Cyp $1 b 1^{-/}$mice (Libby et al., 2003). Cyp1b1/- mice, that are also Tyrdeficient, have more severe iridocorneal angle malformations than Cyp $16 b^{1 \%}$ mice with functional Tyr. Tyris necessary for melanin synthesis and so Tyr ^ mice are albino. The demonstration that Tyr participates in iridocorneal angle development may explain the increased incidence of ASD in people with albinism (van Dorp et al., 1984). Importantly, Tyr also modifies angle phenotypes in another mouse model of ASD. Albino Foxc1 ${ }^{+/}$mice had more severe iridocorneal angle malformations than pigmented Foxc $1^{+/}$mice (Libby et al., 2003). Thus, the effect of Tyr is not specific to Cyp 1 b1 deficiency.

\section{Tyrosinase, tyrosine hydroxylase, dopa and ASD}

TYR converts tyrosine to dihydroxyphenylalanine (L-dopa). Ldopa affects exit from cell cycle and is a precursor of developmentally important catecholamines (Thomas etal., 1995, Zhou et al., 1995, Ilia and Jeffery 1999). Therefore, TYR may contribute to angle development by producing L-dopa. It is possible that Tyr deficiency exacerbates iridocorneal angle malformations due to an L-dopa deficiency. Supplementation of L-dopa to albino Cyp $161^{\%}$ mice greatly alleviated the developmental defects. This proves that Tyr affects anterior segment development through a mechanism involving L-dopa or an L-dopa metabolite (Libby et al., 2003).

Other genes influencing L-dopa signaling may also participate in anterior segment development including dopamine receptors, genes affecting catecholamine metabolism or signaling and genes affecting L-dopa levels. Tyrosine hydroxylase is another enzyme that converts tyrosine to L-dopa. Therefore, tyrosine hydroxylase and genes affecting levels of tyrosine hydroxylase are excellent candidates to affect ocular development. 
Many of the anterior segment development genes discussed in this review can directly or indirectly affect levels of tyrosine hydroxylase. BMP4, PAX6 and LMX1B can promote tyrosine hydroxylase activity or proliferation of tyrosine hydroxylase expressing neural crest cells (Varley and Maxwell 1996, Dellovade et al., 1998, Smidt et al., 2000, Vitalis et al., 2000). Mutations of these genes could affect the supply of L-dopa available to the developing ocular structures. Additionally, tyrosine hydroxylase expression can be regulated by PITX2, PITX3 and TCFAP2 (Cazorla et al., 2000, Kim et al., 2001, Lebel et al., 2001). Finally, CYP1B1 can catalyze a rate limiting step in retinoic acid biosynthesis. Retinoic acid induces Tcfap2a, which can regulate tyrosine hydroxylase and also promotes proliferation of a subset of avian neural crest cells that express tyrosine hydroxylase (Rockwood and Maxwell 1996).

Together, these observations open an exciting new avenue for investigating the role of L-dopa in anterior segment development and glaucoma caused by multiple genes. Since L-dopa participates in angle development and various ocular development genes potentially influence L-dopa (via tyrosine hydroxylase), it is possible that a metabolic defect involving L-dopa is a common theme in ASD and glaucoma.

\section{Common themes and developmental networks}

Normal development requires cross-talk between networks of interacting pathways that have synergistic or opposing effects. The dosage sensitivity of anterior segment development to many of the genes/pathways discussed above implies that a delicate balance of signaling by interacting pathways is required for normal ocular development. Another effect of many of the genes discussed above is a disturbance of ECM composition and abundance. Considering the developmental importance of ECM and the substantial structural and physiological role it has in the trabecular meshwork, it is likely that ECM mis-regulation will be a common consequence of mutations in many genes that cause ASD and glaucoma. In addition to altered ECM regulation, mutations in ECM genes themselves may contribute to ASD. For example, $\mathrm{Co} / 18 \mathrm{a}^{-1}$ mice have malformations of the iris and ciliary body (Ylikarppa etal., 2003). Thus, ECM signaling is one important component of the developmental networks that regulate anterior segment formation.

Despite the genes and pathways discussed above, the developmental networks that regulate anterior segment formation are largely undefined. Many components remain to be identified and the ways in which the known genes interact are not well characterized. As an initial attempt to link the actions of known genes and pathways in anterior segment formation, we suggest how they may relate to TGF $\beta$ family signaling and ECM regulation (Fig. 5). Extending this, TGF $\beta$ family member signaling interacts with other signaling pathways, including fibroblast growth factor signaling, during optic vesicle morphogenesis (Ohkubo et al., 2002). Additionally, Sonic hedgehog signaling can induce competence of a cell to respond to BMP signaling by regulating SMAD expression (Dick et al., 1999, Murtaugh et al., 1999). As an example of how various genes involved in anterior segment formation may converge to affect signaling by a common molecule/ pathway, we indicate known developmental genes that can affect L-dopa or catecholamine mediated developmental events (Fig. 6).
As discussed above, many components of the complicated regulatory/signaling networks controlling anterior segment development remain undefined. Collection of extensive datasets of pertinent biological information in a stage and tissue specific fashion is needed (including mutant phenotypes, gene expression, protein abundance and modification). The production of mouse mutants by gene targeting and transgenic technologies, along with the many new mutants provided by mutagenesis efforts, will be a substantial help in defining network components. To reach an in depth understanding of these networks and how independent networks interact with each other, it will be essential to combine the tools of genomics, molecular biology, developmental biology, bioinformatics and computational biology. The availability of the genome sequence from various species will allow candidate identification of network members in silico and subsequent role testing in vivo. Combining tissue specific gene expression studies with computational methods can identify important configurations of cis-regulatory elements for coordinately regulated genes, (as recently reported for genes responding to similar thresholds of developmental gradients (Stathopoulos et al., 2002). Knowledge of these regulatory elements and genome sequence analysis can then be used to predict roles of other genes for subsequent testing. Continued investment in appropriate electronic and biological resources will poise the field for an unprecedented molecular understanding of anterior segment development.

\section{Acknowledgements}

The authors would like to thank Drs MichaelAnderson, Robert Burgess, Richard Libby and Timothy O'Brien for critical review of the manuscript, Jen Smith and Sara Williamson for work on the figures and Felicia Farley for assistance with references. The authors are supported by National Eye Institute (grant number EY11721, S.W.M.J.), Canadian Institute of Health Research and Heart and Stroke Foundation of Canada (D.B.G.). Scientific support services at The Jackson Laboratory are subsidized by a core grant from the National Cancer Institute (grant CA34196). S.W.M.J. is an Associate Investigator of The Howard Hughes Medical Institute.

\section{References}

ACAMPORA, D., S. MAZAN, V. AVANTAGGIATO, P. BARONE, F. TUORTO, Y. LALLEMAND, P. BRULET and A. SIMEONE. 1996. Epilepsy and brain abnormalities in mice lacking the Otx1 gene. Nat Genet 14: 218-22.

ADAMS, J. C. and F. M. WATT. 1993. Regulation of development and differentiation by the extracellular matrix. Development 117: 1183-98.

ALLEN, L., H. M. BURIAN and A. E. BRALEY. 1955. A new concept of the development of the anterior chamber angle. Arch. Ophthalmol. 53: 783-798.

ALWARD, W. L. 2000. Axenfeld-Rieger syndrome in the age of molecular genetics. Am J Ophthalmo/130: 107-15.

ALWARD, W. L., J. H. FINGERT, M. A. COOTE, A. T. JOHNSON, S. F. LERNER, D. JUNQUA, F. J. DURCAN, P. J. MCCARTNEY, D. A. MACKEY, V. C. SHEFFIELD and E. M. STONE. 1998. Clinical features associated with mutations in the chromosome 1 open-angle glaucoma gene (GLC1A). N Eng/J Med338: 1022-7.

AZUMA, N., A. HIRAKIYAMA, T. INOUE, A. ASAKA and M. YAMADA. 2000. Mutations of a human homologue of the Drosophila eyes absent gene (EYA1) detected in patients with congenital cataracts and ocular anterior segment anomalies. Hum. Mol. Genet. 9: 363-6.

BALEMANS, W. and W. VAN HUL. 2002. Extracellular regulation of BMP signaling in vertebrates: a cocktail of modulators. Dev. Biol. 250: 231-50.

BAULMANN, D. C., A. OHLMANN, C. FLUGEL-KOCH, S. GOSWAMI, A. CVEKL and E. R. TAMM. 2002. Pax6 heterozygous eyes show defects in chamber angle differentiation that are associated with a wide spectrum of other anterior eye segment abnormalities. Mech. Dev. 118: 3-17. 
BEEBE, D. C. and J. M. COATS. 2000. The lens organizes the anterior segment: specification of neural crest cell differentiation in the avian eye. Dev. Biol. 220: 424-31.

BEJJANI, B. A., R. A. LEWIS, K. F. TOMEY, K. L. ANDERSON, D. K. DUEKER, M. JABAK, W. F. ASTLE, B. OTTERUD, M. LEPPERT and J. R. LUPSKI. 1998. Mutations in CYP1B1, the gene for cytochrome P4501B1, are the predominant cause of primary congenital glaucoma in Saudi Arabia. Am J Hum Genet62: 325-33.

BEJJANI, B. A., D. W. STOCKTON, R. A. LEWIS, K. F. TOMEY, D. K. DUEKER, M. JABAK, W. F. ASTLE and J. R. LUPSKI. 2000. Multiple CYP1B1 mutations and incomplete penetrance in an inbred population segregating primary congenital glaucoma suggest frequent de novo events and a dominant modifier locus. Hum Mol Genet 9: 367-74.

BEJJANI, B. A., L. XU, D. ARMSTRONG, J. R. LUPSKI and L. W. RENEKER. 2002. Expression patterns of cytochrome P4501B1 (Cyp1b1) in FVB/N mouse eyes. Exp Eye Res 75: 249-57.

BELMOUDEN, A., R. MELKI, M. HAMDANI, K. ZAGHLOUL, A. AMRAOUI, S. NADIFI, O. AKHAYAT and H. J. GARCHON. 2002. A novel frameshift founder mutation in the cytochrome P450 1B1 (CYP1B1) gene is associated with primary congenital glaucoma in Morocco. Clin Genet62: 334-9.

BLIXT, A., M. MAHLAPUU, M. AITOLA, M. PELTO-HUIKKO, S. ENERBACK and P. CARLSSON. 2000. A forkhead gene, FoxE3, is essential for lens epithelial proliferation and closure of the lens vesicle. Genes Dev. 14: 245-54.

BROWNELL, I., M. DIRKSEN and M. JAMRICH. 2000. Forkhead Foxe3 maps to the dysgenetic lens locus and is critical in lens development and differentiation. Genesis 27: 81-93.

CAZORLA, P., M. P. SMIDT, K. L. O'MALLEY and J. P. BURBACH. 2000. A response element for the homeodomain transcription factor $\mathrm{Ptx} 3$ in the tyrosine hydroxylase gene promoter. J. Neurochem. 74: 1829-1837.

CHANG, B., R. S. SMITH, M. PETERS, O. V. SAVINOVA, N. L. HAWES, A. ZABALETA, S. NUSINOWITZ, J. E. MARTIN, M. L. DAVISSON, C. L. CEPKO, B. L. HOGAN and S. W. JOHN. 2001a. Haploinsufficient Bmp4 ocular phenotypes include anterior segment dysgenesis with elevated intraocular pressure. BMC Genet. 2: 18

CHANG, H., A. L. LAU and M. M. MATZUK. 2001b. Studying TGF-beta superfamily signaling by knockouts and knockins. Mol. Cell. Endocrinol. 180: 39-46.

CHEN, H., W. N. HOWALD and M. R. JUCHAU. 2000. Biosynthesis of all-transretinoic acid from all-trans-retinol: catalysis of all-trans-retinol oxidation by human P-450 cytochromes. Drug Metab. Dispos. 28: 315-322.

CHEN, H., Y. LUN, D. OVCHINNIKOV, H. KOKUBO, K. C. OBERG, C. V. PEPICELLI, L. GAN, B. LEE and R. L. JOHNSON. 1998. Limb and kidney defects in Lmx1b mutant mice suggest an involvement of LMX1B in human nail patella syndrome. Nat Genet 19: 51-5.

CHEN, X., M. J. RUBOCK and M. WHITMAN. 1996. A transcriptional partner for MAD proteins in TGF-beta signalling. Nature 383: 691-6.

CHEN, X., E. WEISBERG, V. FRIDMACHER, M. WATANABE, G. NACO and M. WHITMAN. 1997. Smad4 and FAST-1 in the assembly of activin-responsive factor. Nature 389: 85-9.

CHO, K. W. and I. L. BLITZ. 1998. BMPs, Smads and metalloproteases: extracellular and intracellular modes of negative regulation. Curr Opin Genet Dev 8: 443-9.

CHOW, R. L. and R. A. LANG. 2001. Early eye development in vertebrates. Annu. Rev. Cell Dev. Biol. 17: 255-96.

DATTANI, M. T., J. P. MARTINEZ-BARBERA, P. Q. THOMAS, J. M. BRICKMAN, R. GUPTA, I. L. MARTENSSON, H. TORESSON, M. FOX, J. K. WALES, P. C. HINDMARSH, S. KRAUSS, R. S. BEDDINGTON and I. C. ROBINSON. 1998. Mutations in the homeobox gene HESX1/Hesx1 associated with septo-optic dysplasia in human and mouse. Nat Genet 19: 125-33.

DELLOVADE, T. L., D. W. PFAFF and M. SCHWANZEL-FUKUDA. 1998. Olfactory bulb development is altered in small-eye (Sey) mice. J. Comp. Neurol. 402: 402418.

DENISON, M. S., J. M. FISHER and J. P. WHITLOCK, JR. 1989. Protein-DNA interactions at recognition sites for the dioxin-Ah receptor complex. JBiolChem 264: 16478-82.

DICK, A., A. MEIER and M. HAMMERSCHMIDT. 1999. Smad1 and Smad5 have distinct roles during dorsoventral patterning of the zebrafish embryo. Dev Dyn 216: $285-98$.
DIMANLIG, P. V., S. C. FABER, W. AUERBACH, H. P. MAKARENKOVA and R. A. LANG. 2001. The upstream ectoderm enhancer in Pax6 has an important role in lens induction. Development 128: 4415-24.

DOLWICK, K. M., H. I. SWANSON and C. A. BRADFIELD. 1993. In vitro analysis of Ah receptor domains involved in ligand-activated DNA recognition. Proc Nat/ Acad Sci USA 90: 8566-70.

DOWARD, W., R. PERVEEN, I. C. LLOYD, A. E. RIDGWAY, L. WILSON and G. C. BLACK. 1999. A mutation in the RIEG1 gene associated with Peters' anomaly. JMed Genet 36: 152-5.

DREYER, S. D., G. ZHOU, A. BALDINI, A. WINTERPACHT, B. ZABEL, W. COLE, R. L. JOHNSON and B. LEE. 1998. Mutations in LMX1B cause abnormal skeletal patterning and renal dysplasia in nail patella syndrome. Nat Genet 19: 47-50.

FANTES, J., N. K. RAGGE, S. A. LYNCH, N. I. MCGILL, J. R. COLLIN, P. N. HOWARD-PEEBLES, C. HAYWARD, A. J. VIVIAN, K. WILLIAMSON, V. VAN HEYNINGEN and D. R. FITZPATRICK. 2003. Mutations in SOX2 cause anophthalmia. Nat. Genet. 33: 461-3.

FREUND, C., D. J. HORSFORD and R. R. MCINNES. 1996. Transcription factor genes and the developing eye: a genetic perspective. Hum Mol Genet5: 1471-88.

FUHRMANN, S., E. M. LEVINE and T. A. REH. 2000. Extraocular mesenchyme patterns the optic vesicle during early eye development in the embryonic chick. Development 127: 4599-4609.

FURUTA, Y. and B. L. HOGAN. 1998. BMP4 is essential for lens induction in the mouse embryo. Genes Dev. 12: 3764-75.

GAGE, P. J., H. SUH and S. A. CAMPER. 1999. Dosage requirement of Pitx2 for development of multiple organs. Development 126: 4643-51.

GERMAIN, S., M. HOWELL, G. M. ESSLEMONT and C. S. HILL. 2000. Homeodomain and winged-helix transcription factors recruit activated Smads to distinct promoter elements via a common Smad interaction motif. Genes Dev 14: 435-51.

GLASER, T., L. JEPEAL, J. G. EDWARDS, S. R. YOUNG, J. FAVOR and R. L. MAAS. 1994. PAX6 gene dosage effect in a family with congenital cataracts, aniridia, anophthalmia and central nervous system defects. Nat Genet 7: 46371.

GOULD, D. B. and S. W. JOHN. 2002. Anterior segment dysgenesis and the developmental glaucomas are complex traits. Hum. Mol. Genet. 11: 1185-93.

GRAHAM, A., P. FRANCIS-WEST, P. BRICKELL and A. LUMSDEN. 1994. The signalling molecule BMP4 mediates apoptosis in the rhombencephalic neural crest. Nature 372: 684-6.

GRIMM, C., B. CHATTERJEE, J. FAVOR, T. IMMERVOLL, J. LOSTER, N. KLOPP, R. SANDULACHE and J. GRAW. 1998. Aphakia (ak), a mouse mutation affecting early eye development: fine mapping, consideration of candidate genes and altered Pax6 and Six3 gene expression pattern. Dev. Genet.23:299316.

GRINDLEY, J. C., D. R. DAVIDSON and R. E. HILL. 1995. The role of Pax-6 in eye and nasal development. Development 121: 1433-42.

HALDER, G., P. CALLAERTS and W. J. GEHRING. 1995. Induction of ectopic eyes by targeted expression of the eyeless gene in Drosophila. Science 267: 178892.

HAMANAKA, T., A. BILL, R. ICHINOHASAMA and T. ISHIDA. 1992. Aspects of the development of Schlemm's canal. Exp. Eye Res. 55: 479-88.

HANSON, I. M., J. M. FLETCHER, T. JORDAN, A. BROWN, D. TAYLOR, R. J. ADAMS, H. H. PUNNETT and V. VAN HEYNINGEN. 1994. Mutations at the PAX6 locus are found in heterogeneous anterior segment malformations including Peters' anomaly. Nat Genet 6: 168-73.

HANSON, I. M., A. SEAWRIGHT, K. HARDMAN, S. HODGSON, D. ZALETAYEV, G. FEKETE and V. VAN HEYNINGEN. 1993. PAX6 mutations in aniridia. Hum Mol Genet 2: 915-20.

HAUSTEIN, J. 1983. On the ultrastructure of the developing and adult mouse corneal stroma. Anat. Embryol. (Berl) 168: 291-305.

HEANUE, T. A., R. J. DAVIS, D. H. ROWITCH, A. KISPERT, A. P. MCMAHON, G. MARDON and C. J. TABIN. 2002. Dach1, a vertebrate homologue of Drosophila dachshund, is expressed in the developing eye and ear of both chick and mouse and is regulated independently of Pax and Eya genes. Mech. Dev. 111: 75-87.

HEANUE, T. A., R. RESHEF, R. J. DAVIS, G. MARDON, G. OLIVER, S. TOMAREV, A. B. LASSAR and C. J. TABIN. 1999. Synergistic regulation of vertebrate 
muscle development by Dach2, Eya2 and Six1, homologs of genes required for Drosophila eye formation. Genes Dev 13: 3231-43.

HIEMISCH, H., A. P. MONAGHAN, G. SCHUTZ and K. H. KAESTNER. 1998. Expression of the mouse Fkh1/Mf1 and Mfh1 genes in late gestation embryos is restricted to mesoderm derivatives. Mech. Dev. 73: 129-132.

HILL, R. E., J. FAVOR, B. L. HOGAN, C. C. TON, G. F. SAUNDERS, I. M. HANSON, J. PROSSER, T. JORDAN, N. D. HASTIE and V. VAN HEYNINGEN. 1991. Mouse small eye results from mutations in a paired-like homeobox-containing gene. Nature 354: 522-5

HJALT, T. A., B. A. AMENDT and J. C. MURRAY. 2001. PITX2 regulates procollagen lysyl hydroxylase (PLOD) gene expression: implications for the pathology of Rieger syndrome. J. Cell Biol. 152: 545-52.

HJALT, T. A., E. V. SEMINA, B. A. AMENDT and J. C. MURRAY. 2000. The Pitx2 protein in mouse development. Dev. Dyn. 218: 195-200.

HOGAN, B. L. 1996. Bone morphogenetic proteins: multifunctional regulators of vertebrate development. Genes Dev. 10: 1580-1594.

HOGAN, B. L. 1999. Morphogenesis. Cel/96: 225-233.

HOGAN, B. L., G. HORSBURGH, J. COHEN, C. M. HETHERINGTON, G. FISHER and M. F. LYON. 1986. Small eyes (Sey): a homozygous lethal mutation on chromosome 2 which affects the differentiation of both lens and nasal placodes in the mouse. J Embryol Exp Morpho/97: 95-110.

HONG, H. K., J. H. LASS and A. CHAKRAVARTI. 1999. Pleiotropic skeletal and ocular phenotypes of the mouse mutation congenital hydrocephalus (ch/Mf1) arise from a winged helix/forkhead transcriptionfactor gene. Hum Mol Genet8: 625-37.

HONKANEN, R. A., D. Y. NISHIMURA, R. E. SWIDERSKI, S. R. BENNETT, S. HONG, Y. H. KWON, E. M. STONE, V. C. SHEFFIELD and W. L. ALWARD. 2003. A family with Axenfeld-Rieger syndrome and Peters Anomaly caused by a point mutation (Phe112Ser) in the FOXC1 gene. Am JOphthalmo/135: 36875.

HSIEH, Y. W., X. M. ZHANG, E. LIN, G. OLIVER and X. J. YANG. 2002. The homeobox gene Six3 is a potential regulator of anterior segment formation in the chick eye. Dev. Biol. 248: 265-80.

ILIA, M. and G. JEFFERY. 1999. Retinal mitosis is regulated by dopa, a melanin precursor that may influence the time at which cells exit the cell cycle: analysis of patterns of cell production in pigmented and albino retinae. J. Comp. Neurol. 405: 394-405.

JACOBSON, A. G. and A. K. SATER. 1988. Features of embryonic induction. Development 104: 341-59.

JAMIESON, R. V., R. PERVEEN, B. KERR, M. CARETTE, J. YARDLEY, E. HEON, M. G. WIRTH, V. VAN HEYNINGEN, D. DONNAI, F. MUNIER and G. C. BLACK. 2002. Domain disruption and mutation of the bZIP transcription factor, MAF, associated with cataract, ocular anterior segment dysgenesis and coloboma. Hum Mol Genet 11: 33-42.

JOHNSTON, M. C., D. M. NODEN, R. D. HAZELTON, J. L. COULOMBRE and A. J. COULOMBRE. 1979. Origins of avian ocular and periocular tissues. Exp. Eye Res. 29: 27-43.

JORDAN, T., I. HANSON, D. ZALETAYEV, S. HODGSON, J. PROSSER, A. SEAWRIGHT, N. HASTIE and V. VAN HEYNINGEN. 1992. The human PAX6 gene is mutated in two patients with aniridia. Nat Genet 1: 328-32.

KAISER-KUPFER, M. I. 1989. Neural crest origin of trabecular meshwork cells and other structures of the anterior chamber. Am. J. Ophthalmol. 107: 671-2.

KAUFMAN, M. H. 1995. The Atlas of Mouse Development. Academic Press, San Diego.

KAWAUCHI, S., S. TAKAHASHI, O. NAKAJIMA, H. OGINO, M. MORITA, M. NISHIZAWA, K. YASUDA and M. YAMAMOTO. 1999. Regulation of lens fiber cell differentiation by transcription factor c-Maf. J Biol Chem 274: 19254-60.

KIDSON, S. H., T. KUME, K. DENG, V. WINFREY and B. L. HOGAN. 1999. The forkhead/winged-helix gene, Mf1, is necessary for the normal development of the cornea and formation of the anterior chamber in the mouse eye. Dev. Biol. 211: 306-22.

KIM, H. S., S. J. HONG, M. S. LEDOUX and K. S. KIM. 2001. Regulation of the tyrosine hydroxylase and dopamine beta-hydroxylase genes by the transcription factor AP-2. JNeurochem 76: 280-94.

KIM, J. I., T. LI, I. C. HO, M. J. GRUSBY and L. H. GLIMCHER. 1999. Requirement for the c-Maf transcription factor in crystallin gene regulation and lens development. Proc. Natl. Acad. Sci. USA 96: 3781-5.

KIVIRIKKO, K. I. and R. MYLLYLA. 1985. Post-translational processing of procollagens. Ann N Y Acad Sci460: 187-201.

KOROMA, B. M., J. M. YANG and O. H. SUNDIN. 1997. The Pax-6 homeobox gene is expressed throughout the corneal and conjunctival epithelia. Invest Ophthalmol Vis Sci38: 108-20.

KOZLOWSKI, K. and M. A. WALTER. 2000. Variation in residual PITX2 activity underlies the phenotypic spectrum of anterior segment developmental disorders. Hum Mol Genet 9: 2131-9.

KOZMIK, Z., P. PFEFFER, J. KRALOVA, J. PACES, V. PACES, A. KALOUSOVA and A. CVEKL. 1999. Molecular cloning and expression of the human and mouse homologues of the Drosophila dachshund gene. Dev Genes Evo/209: 537-45.

KULAK, S. C., K. KOZLOWSKI, E. V. SEMINA, W. G. PEARCE and M. A. WALTER. 1998. Mutation in the RIEG1 gene in patients with iridogoniodysgenesis syndrome. Hum Mol Genet 7: 1113-7.

KUME, T., K. Y. DENG, V. WINFREY, D. B. GOULD, M. A. WALTER and B. L. HOGAN. 1998. The forkhead/winged helix gene Mf1 is disrupted in the pleiotropic mouse mutation congenital hydrocephalus. Ce//93: 985-96.

KUPFER, C. and M. I. KAISER-KUPFER. 1978. New hypothesis of developmental anomalies of the anterior chamber associated with glaucoma. Trans. Ophthalmol. Soc. U. K. 98: 213-5.

KUPFER, C. and M. I. KAISER-KUPFER. 1979. Observations on the development of the anterior chamber angle with reference to the pathogenesis of congenital glaucomas. Am. J. Ophthalmol. 88: 424-6.

LEBEL, M., Y. GAUTHIER, A. MOREAU and J. DROUIN. 2001. Pitx3 activates mouse tyrosine hydroxylase promoter via a high-affinity binding site. $J$. Neurochem. 77: 558-567.

LEHMANN, O. J., N. D. EBENEZER, T. JORDAN, M. FOX, L. OCAKA, A. PAYNE, B. P. LEROY, B. J. CLARK, R. A. HITCHINGS, S. POVEY, P. T. KHAW and S. S. BHATTACHARYA. 2000. Chromosomal duplication involving the forkhead transcription factor gene FOXC1 causes iris hypoplasia and glaucoma. $\mathrm{Am} \mathrm{J}$ Hum Genet 67: 1129-35.

LIBBY, R. T., R. S. SMITH, O. V. SAVINOVA, A. ZABALETA, J. E. MARTIN, F. J. GONZALEZ and S. W. JOHN. 2003. Modification of ocular defects in mouse developmental glaucoma models by tyrosinase. Science 299: 1578-81.

LICHTER, P. R., J. E. RICHARDS, C. A. DOWNS, H. M. STRINGHAM, M. BOEHNKE and F. A. FARLEY. 1997. Cosegregation of open-angle glaucoma and the nail-patella syndrome. Am J Ophthalmo/124: 506-15.

LIN, C. Q. and M. J. BISSELL. 1993. Multi-faceted regulation of cell differentiation by extracellular matrix. FASEB $J 7$ : 737-43.

LIN, C. R., C. KIOUSSI, S. O'CONNELL, P. BRIATA, D. SZETO, F. LIU, J. C. IZPISUA-BELMONTE and M. G. ROSENFELD. 1999. Pitx2 regulates lung asymmetry, cardiac positioning and pituitary and tooth morphogenesis. Nature 401: 279-82.

LIU, B., C. L. DOU, L. PRABHU and E. LAI. 1999. FAST-2 is a mammalian wingedhelix protein which mediates transforming growth factor beta signals. $\mathrm{Mo} / \mathrm{Ce} / \mathrm{l}$ Biol19: 424-30.

LOGAN, M., S. M. PAGAN-WESTPHAL, D. M. SMITH, L. PAGANESSI and C. J. TABIN. 1998. The transcription factor Pitx2 mediates situs-specific morphogenesis in response to left-right asymmetric signals. Cel/94: 307-17.

LU, M. F., C. PRESSMAN, R. DYER, R. L. JOHNSON and J. F. MARTIN. 1999 Function of Rieger syndrome gene in left-right asymmetry and craniofacial development. Nature 401: 276-8.

LYON, M. F., R. V. JAMIESON, R. PERVEEN, P. H. GLENISTER, R. GRIFFITHS, Y. BOYD, L. H. GLIMCHER, J. FAVOR, F. L. MUNIER and G. C. BLACK. 2003. A dominant mutation within the DNA-binding domain of the bZIP transcription factor Maf causes murine cataract and results in selective alteration in DNA binding. Hum. Mol. Genet. 12: 585-94.

MABIE, P. C., M. F. MEHLER and J. A. KESSLER. 1999. Multiple roles of bone morphogenetic protein signaling in the regulation of cortical cell number and phenotype. JNeurosci19: 7077-88.

MATHERS, P. H., A. GRINBERG, K. A. MAHON and M. JAMRICH. 1997. The Rx homeobox gene is essential for vertebrate eye development. Nature 387: 603-7. 
MAUMENEE, E. A. 1958. The pathogenesis of congenital glaucoma: a new theory. Trans. Am. Ophthalmol. Soc. 56: 507-570.

MCINTOSH, I., S. D. DREYER, M. V. CLOUGH, J. A. DUNSTON, W. EYAID, C. M. ROIG, T. MONTGOMERY, S. ALA-MELLO, I. KAITILA, A. WINTERPACHT, B. ZABEL, M. FRYDMAN, W. G. COLE, C. A. FRANCOMANO and B. LEE. 1998. Mutation analysis of LMX1B gene in nail-patella syndrome patients. Am J Hum Genet 63: 1651-8.

MEARS, A. J., T. JORDAN, F. MIRZAYANS, S. DUBOIS, T. KUME, M. PARLEE, R. RITCH, B. KOOP, W. L. KUO, C. COLLINS, J. MARSHALL, D. B. GOULD, W. PEARCE, P. CARLSSON, S. ENERBACK, J. MORISSETTE, S. BHATTACHARYA, B. HOGAN, V. RAYMOND and M. A. WALTER. 1998. Mutations of the forkhead/winged-helix gene, FKHL7, in patients with AxenfeldRieger anomaly. Am J Hum Genet 63: 1316-28.

MIRZAYANS, F., D. B. GOULD, E. HEON, G. D. BILLINGSLEY, J. C. CHEUNG, A. J. MEARS and M. A. WALTER. 2000. Axenfeld-Rieger syndrome resulting from mutation of the FKHL7 gene on chromosome 6p25. Eur J Hum Genet 8: 71-4.

MIYAZONO, K., K. KUSANAGI and H. INOUE. 2001. Divergence and convergence of TGF-beta/BMP signaling. J. Cell Physiol. 187: 265-76.

MORELLO, R., G. ZHOU, S. D. DREYER, S. J. HARVEY, Y. NINOMIYA, P. S. THORNER, J. H. MINER, W. COLE, A. WINTERPACHT, B. ZABEL, K. C. OBERG and B. LEE. 2001. Regulation of glomerular basement membrane collagen expression by LMX1B contributes to renal disease in nail patella syndrome. Nat. Genet. 27: 205-8.

MURTAUGH, L. C., J. H. CHYUNG and A. B. LASSAR. 1999. Sonic hedgehog promotes somitic chondrogenesis by altering the cellular response to BMP signaling. Genes Dev 13: 225-37.

NISHIMURA, D. Y., C. C. SEARBY, W. L. ALWARD, D. WALTON, J. E. CRAIG, D. A. MACKEY, K. KAWASE, A. B. KANIS, S. R. PATIL, E. M. STONE and V. C. SHEFFIELD. 2001. A spectrum of FOXC1 mutations suggests gene dosage as a mechanism for developmental defects of the anterior chamber of the eye. $\mathrm{Am}$ J Hum Genet 68: 364-72.

NISHIMURA, D. Y., R. E. SWIDERSKI, W. L. ALWARD, C. C. SEARBY, S. R. PATIL, S. R. BENNET, A. B. KANIS, J. M. GASTIER, E. M. STONE and V. C. SHEFFIELD. 1998. The forkhead transcription factor gene FKHL7 is responsible for glaucoma phenotypes which map to 6p25. Nat Genet 19: 140-7.

NODEN, D. M. 1975. An analysis of migratory behavior of avian cephalic neural crest cells. Dev. Biol. 42: 106-30.

OGINO, H. and K. YASUDA. 1998. Induction of lens differentiation by activation of a bZIP transcription factor, L-Maf. Science 280: 115-8.

OH, S. P. and E. LI. 1997. The signaling pathway mediated by the type IIB activin receptor controls axial patterning and lateral asymmetry in the mouse. Genes Dev 11: 1812-26.

OHKUBO, Y., C. CHIANG and J. L. RUBENSTEIN. 2002. Coordinate regulation and synergistic actions of BMP4, SHH and FGF8 in the rostral prosencephalon regulate morphogenesis of the telencephalic and optic vesicles. Neuroscience 111: 1-17.

OLIVER, G., A. MAILHOS, R. WEHR, N. G. COPELAND, N. A. JENKINS and P. GRUSS. 1995. Six3, a murine homologue of the sine oculis gene, demarcates the most anterior border of the developing neural plate and is expressed during eye development. Development 121: 4045-55.

ORMESTAD, M., A. BLIXT, A. CHURCHILL, T. MARTINSSON, S. ENERBACK and P. CARLSSON. 2002. Foxe3 haploinsufficiency in mice: a model for Peters' anomaly. Invest. Ophthalmol. Vis. Sci. 43: 1350-7.

PEI, Y. F. and J. A. RHODIN. 1970. The prenatal development of the mouse eye. Anat. Rec. 168: 105-25.

PERRIS, R. 1997. The extracellular matrix in neural crest-cell migration. Trends Neurosci. 20: 23-31.

PHILLIPS, J. C. 2002. Four novel mutations in the PITX2 gene in patients with Axenfeld-Rieger syndrome. Ophthalmic Res 34: 324-6.

PICHAUD, F. and C. DESPLAN. 2002. Pax genes and eye organogenesis. Curr Opin Genet Dev 12: 430-4.

PIEDRA, M. E., J. M. ICARDO, M. ALBAJAR, J. C. RODRIGUEZ-REY and M. A. ROS. 1998. Pitx2 participates in the late phase of the pathway controlling leftright asymmetry. Cel/94: 319-24.

PIGNONI, F., B. HU, K. H. ZAVITZ, J. XIAO, P. A. GARRITY and S. L. ZIPURSKY. 1997. The eye-specification proteins So and Eya form a complex and regulate multiple steps in Drosophila eye development. Cel/91: 881-91.

PLASILOVA, M., I. STOILOV, M. SARFARAZI, L. KADASI, E. FERAKOVA and V. FERAK. 1999. Identification of a single ancestral CYP1B1 mutation in Slovak Gypsies (Roms) affected with primary congenital glaucoma. J Med Genet 36: 290-4.

PRESSMAN, C. L., H. CHEN and R. L. JOHNSON. 2000. LMX1B, a LIM homeodomain class transcription factor, is necessary for normal development of multiple tissues in the anterior segment of the murine eye. Genesis 26: 15-25.

PRISTON, M., K. KOZLOWSKI, D. GILL, K. LETWIN, Y. BUYS, A. V. LEVIN, M. A. WALTER and E. HEON. 2001. Functional analyses of two newly identified PITX2 mutants reveal a novel molecular mechanism for Axenfeld-Rieger syndrome. Hum Mol Genet 10: 1631-8.

QUIGLEY, H. A. 1996. Number of people with glaucoma worldwide. Br. J. Ophthalmol. 80: 389-393.

RENEKER, L. W., D. W. SILVERSIDES, L. XU and P. A. OVERBEEK. 2000. Formation of corneal endothelium is essential for anterior segment development - a transgenic mouse model of anterior segment dysgenesis. Development 127 : 533-42.

REYES, H., S. REISZ-PORSZASZ and O. HANKINSON. 1992. Identification of the Ah receptor nuclear translocator protein (Arnt) as a component of the DNA binding form of the Ah receptor. Science 256: 1193-5.

ROCKWOOD, J. M. and G. D. MAXWELL. 1996. An analysis of the effects of retinoic acid and other retinoids on the development of adrenergic cells from the avian neural crest. Exp. Cell Res. 223: 250-258.

RYAN, A. K., B. BLUMBERG, C. RODRIGUEZ-ESTEBAN, S. YONEI-TAMURA, K. TAMURA, T. TSUKUI, J. DE LA PENA, W. SABBAGH, J. GREENWALD, S. CHOE, D. P. NORRIS, E. J. ROBERTSON, R. M. EVANS, M. G. ROSENFELD and J. C. IZPISUA BELMONTE. 1998. Pitx2 determines left-right asymmetry of internal organs in vertebrates. Nature 394: 545-51.

SAIKA, S., C. Y. LIU, M. AZHAR, L. P. SANFORD, T. DOETSCHMAN, R. L. GENDRON, C. W. KAO and W. W. KAO. 2001. TGFbeta2 in corneal morphogenesis during mouse embryonic development. Dev. Biol. 240: 419-32.

SALEEM, R. A., S. BANERJEE-BASU, F. B. BERRY, A. BAXEVANIS and M. A. WALTER. 2003a. Structural and Functional Analyses of Disease Causing Missense Mutations in the Forkhead Domain of FOXC1. Hum Mol Genet.

SALEEM, R. A., S. BANERJEE-BASU, F. B. BERRY, A. D. BAXEVANIS and M. A. WALTER. 2001. Analyses of the effects that disease-causing missense mutations have on the structure and function of the winged-helix protein FOXC1. Am J Hum Genet 68: 627-41.

SALEEM, R. A., T. C. MURPHY, J. M. LIEBMANN and M. A. WALTER. 2003b. Identification and Analysis of a Novel Mutation in the FOXC1 Forkhead Domain. Invest Ophthalmol Vis Sci44: 4608-12.

SANYAL, S. and R. K. HAWKINS. 1979. Dysgenetic lens (dyl) - a new gene in the mouse. Invest Ophthalmol Vis Sci18: 642-5.

SARFARAZI, M. and I. STOILOV. 2000. Molecular genetics of primary congenital glaucoma. Eye 14: 422-8.

SEMINA, E. V., I. BROWNELL, H. A. MINTZ-HITTNER, J. C. MURRAY and M. JAMRICH. 2001. Mutations in the human forkhead transcription factor FOXE3 associated with anterior segment ocular dysgenesis and cataracts. Hum Mol Genet 10: 231-6.

SEMINA, E. V., R. E. FERRELL, H. A. MinTZ-HITTNER, P. BITOUN, W. L. ALWARD, R. S. REITER, C. FUNKHAUSER, S. DAACK-HIRSCH and J. C. MURRAY. 1998. A novel homeobox gene PITX3 is mutated in families with autosomal-dominant cataracts and ASMD. Nat Genet 19: 167-70.

SEMINA, E. V., J. C. MURRAY, R. REITER, R. F. HRSTKA and J. GRAW. 2000. Deletion in the promoter region and altered expression of Pitx3 homeobox gene in aphakia mice. Hum Mol Genet 9: 1575-85.

SEMINA, E. V., R. REITER, N. J. LEYSENS, W. L. ALWARD, K. W. SMALL, N. A. DATSON, J. SIEGEL-BARTELT, D. BIERKE-NELSON, P. BITOUN, B. U. ZABEL, J. C. CAREY and J. C. MURRAY. 1996. Cloning and characterization of a novel bicoid-related homeobox transcription factor gene, RIEG, involved in Rieger syndrome. Nat Genet 14: 392-9.

SHEHIN, S. E., R. O. STEPHENSON and W. F. GREENLEE. 2000. Transcriptional regulation of the human $\mathrm{CYP} 1 \mathrm{~B} 1$ gene. Evidence for involvement of an aryl hydrocarbon receptor response element in constitutive expression. JBiol Chem 275: $6770-6$. 
SHIELDS, M. B., E. BUCKLEY, G. K. KLINTWORTH and R. THRESHER. 1985. Axenfeld-Rieger syndrome. A spectrum of developmental disorders. Surv. Ophthalmol. 29: 387-409.

SHIRATORI, H., R. SAKUMA, M. WATANABE, H. HASHIGUCHI, K. MOCHIDA, Y. SAKAI, J. NISHINO, Y. SAIJOH, M. WHITMAN and H. HAMADA. 2001. Twostep regulation of left-right asymmetric expression of Pitx2: initiation by nodal signaling and maintenance by Nkx2. Mol Cel/7: 137-49.

SMIDT, M. P., C. H. ASBREUK, J. J. COX, H. CHEN, R. L. JOHNSON and J. P. BURBACH. 2000. A second independent pathway for development of mesencephalic dopaminergic neurons requires Lmx1b. Nat. Neurosci. 3: 337341.

SMITH, R. S., A. ZABALETA, T. KUME, O. V. SAVINOVA, S. H. KIDSON, J. E. MARTIN, D. Y. NISHIMURA, W. L. ALWARD, B. L. HOGAN and S. W. JOHN. 2000. Haploinsufficiency of the transcription factors FOXC1 and FOXC2 results in aberrant ocular development. Hum Mol Genet 9: 1021-32.

SMITH, R. S., A. ZABALETA, O. V. SAVINOVA and S. W. JOHN. 2001. The mouse anterior chamber angle and trabecular meshwork develop without cell death. BMC Dev Biol1: 3.

STATHOPOULOS, A., M. VAN DRENTH, A. ERIVES, M. MARKSTEIN and M. LEVINE. 2002. Whole-genome analysis of dorsal-ventral patterning in the Drosophila embryo. Cel/111: 687-701.

STOILOV, I., A. N. AKARSU and M. SARFARAZI. 1997. Identification of three different truncating mutations in cytochrome P4501B1 (CYP1B1) as the principal cause of primary congenital glaucoma (Buphthalmos) in families linked to the GLC3A locus on chromosome 2p21. Hum Mol Genet 6: 641-7.

SUTTER, T. R., Y. M. TANG, C. L. HAYES, Y. Y. WO, E. W. JABS, X. LI, H. YIN, C. W. CODY and W. F. GREENLEE. 1994. Complete cDNA sequence of a human dioxin-inducible mRNA identifies a new gene subfamily of cytochrome P450 that maps to chromosome 2. J Biol Chem 269: 13092-9.

THOMAS, S. A., A. M. MATSUMOTO and R. D. PALMITER. 1995. Noradrenaline is essential for mouse fetal development. Nature 374: 643-646.

THYLEFORS, B. and A. D. NEGREL. 1994. The global impact of glaucoma. Bull World Health Organ 72: 323-326.

TON, C. C., H. HIRVONEN, H. MIWA, M. M. WEIL, P. MONAGHAN, T. JORDAN, V. VAN HEYNINGEN, N. D. HASTIE, H. MEIJERS-HEIJBOER, M. DRECHSLER and ET AL., 1991. Positional cloning and characterization of a paired box- and homeobox-containing gene from the aniridia region. Cel/67: 1059-74.

TRAINOR, P. A. and P. P. TAM. 1995. Cranial paraxial mesoderm and neural crest cells of the mouse embryo: co-distribution in the craniofacial mesenchyme but distinct segregation in branchial arches. Development 121: 2569-82.

TREISMAN, J. E. 1999. A conserved blueprint for the eye? Bioessays 21: 843-50.

TRIPATHI, B. J. and R. C. TRIPATHI. 1989. Neural crest origin of human trabecular meshwork and its implications for the pathogenesis of glaucoma. Am. J. Ophthalmol. 107: 583-90.

VAN DORP, D. B., J. W. DELLEMAN and D. H. LOEWER SIEGER. 1984. Oculocutaneous albinism and anterior chambre cleavage malformations. Not a coincidence. Clin. Genet. 26: 440-444.

VAN HEYNINGEN, V. and K. A. WILLIAMSON. 2002. PAX6 in sensory development. Hum Mol Genet 11: 1161-7.

VARLEY, J. E. and G. D. MAXWELL. 1996. BMP-2 and BMP-4, but not BMP-6, increase the number of adrenergic cells which develop in quail trunk neural crest cultures. Exp. Neurol. 140: 84-94.

VITALIS, T., O. CASES, D. ENGELKAMP, C. VERNEY and D. J. PRICE. 2000. Defect of tyrosine hydroxylase-immunoreactive neurons in the brains of mice lacking the transcription factor Pax6. J. Neurosci. 20: 6501-6516.
VOLLRATH, D., V. L. JARAMILLO-BABB, M. V. CLOUGH, I. MCINTOSH, K. M. SCOTT, P. R. LICHTER and J. E. RICHARDS. 1998. Loss-of-function mutations in the LIM-homeodomain gene, LMX1B, in nail-patella syndrome. Hum Mol Genet 7: 1091-8.

WALTHER, C. and P. GRUSS. 1991. Pax-6, a murine paired box gene, is expressed in the developing CNS. Development 113: 1435-49.

WARING, G. O., M. M. RODRIGUES and P. R. LAIBSON. 1975. Anterior chamber cleavage syndrome. A stepladder classification. Surv. Ophthalmol. 20: 3-27.

WAWERSIK, S. and R. L. MAAS. 2000. Vertebrate eye development as modeled in Drosophila. Hum Mol Genet 9: 917-25.

WEISBERG, E., G. E. WINNIER, X. CHEN, C. L. FARNSWORTH, B. L. HOGAN and M. WHITMAN. 1998. A mouse homologue of FAST-1 transduces TGF beta superfamily signals and is expressed during early embryogenesis. Mech Dev 79: 17-27.

WEST-MAYS, J. A., J. ZHANG, T. NOTTOLI, S. HAGOPIAN-DONALDSON, D. LIBBY, K. J. STRISSEL and T. WILLIAMS. 1999. AP-2alpha transcription factor is required for early morphogenesis of the lens vesicle. Dev Bio/206: 46-62.

WINNIER, G. E., L. HARGETT and B. L. HOGAN. 1997. The winged helix transcription factor $\mathrm{MFH} 1$ is required for proliferation and patterning of paraxial mesoderm in the mouse embryo. Genes Dev. 11: 926-40.

WINNIER, G. E., T. KUME, K. Y. DENG, R. ROGERS, J. BUNDY, C. RAINES, M. A. WALTER, B. L. M. HOGAN and S. J. CONWAY. 1999. Roles for the winged helix transcription factors MF1 and MFH1 in cardiovascular development revealed by nonallelic noncomplementation of null alleles. Dev. Biol. 213: 418-431.

XU, P. X., J. ADAMS, H. PETERS, M. C. BROWN, S. HEANEY and R. MAAS. 1999a. Eya1-deficient mice lack ears and kidneys and show abnormal apoptosis of organ primordia. Nat. Genet. 23: 113-7.

XU, P. X., I. WOO, H. HER, D. R. BEIER and R. L. MAAS. 1997. Mouse Eya homologues of the Drosophila eyes absent gene require Pax6 for expression in lens and nasal placode. Development 124: 219-31.

XU, P. X., X. ZHANG, S. HEANEY, A. YOON, A. M. MICHELSON and R. L. MAAS. 1999b. Regulation of Pax6 expression is conserved between mice and flies. Development 126: 383-95.

YLIKARPPA, R., L. EKLUND, R. SORMUNEN, A. I. KONTIOLA, A. UTRIAINEN, M. MAATTA, N. FUKAI, B. R. OLSEN and T. PIHLAJANIEMI. 2003. Lack of type $\mathrm{XVIII}$ collagen results in anterior ocular defects. FASEB J.

YOSHIDA, K., J. IMAKI, Y. KOYAMA, T. HARADA, Y. SHINMEI, C. OISHI, Y. MATSUSHIMA-HIBIYA, A. MATSUDA, S. NISHI, H. MATSUDA and M. SAKAI. 1997. Differential expression of maf-1 and maf-2 genes in the developing rat lens. Invest Ophthalmol Vis Sci38: 2679-83.

YOSHIOKA, H., C. MENO, K. KOSHIBA, M. SUGIHARA, H. ITOH, Y. ISHIMARU, T. INOUE, H. OHUCHI, E. V. SEMINA, J. C. MURRAY, H. HAMADA and S. NOJI. 1998. Pitx2, a bicoid-type homeobox gene, is involved in a lefty-signaling pathway in determination of left-right asymmetry. Ce//94: 299-305.

YUE, B. Y. 1996. The extracellular matrix and its modulation in the trabecular meshwork. Surv Ophthalmo/40: 379-90.

ZHAO, S., Q. CHEN, F. C. HUNG and P. A. OVERBEEK. 2002. BMP signaling is required for development of the ciliary body. Development 129: 4435-42.

ZHOU, Q. Y., C. J. QUAIFE and R. D. PALMITER. 1995. Targeted disruption of the tyrosine hydroxylase gene reveals that catecholamines are required for mouse fetal development. Nature 374: 640-643.

ZUBER, M. E., G. GESTRI, A. S. VICZIAN, G. BARSACCHI and W. A. HARRIS. 2003. Specification of the vertebrate eye by a network of eye field transcription factors. Development 130: 5155-67. 